BIBLIOTECA VIRTUAL DE CIÊNCIAS HUMANAS

\title{
LinguageM E PRODUÇÃO DE SENTIDOS NO COTIDIANO
}

\author{
Mary Jane Spink
} T2entro edelstein de pesquisas sociais 


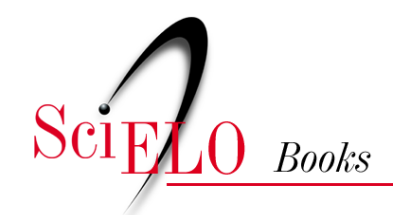

\title{
Linguagem e produção de sentidos no cotidiano
}

\author{
Mary Jane Spink
}

\section{SciELO Books / SciELO Livros / SciELO Libros}

SPINK, MJ. Linguagem e produção de sentidos no cotidiano [online]. Rio de Janeiro: Centro Edelstein de Pesquisas Sociais, 2010. 72 p. ISBN: 978-85-7982-046-5. Available from SciELO Books <http://books.scielo.org>.

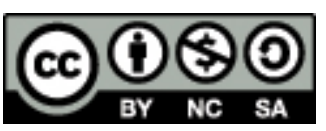

All the contents of this chapter, except where otherwise noted, is licensed under a Creative Commons Attribution-Non Commercial-ShareAlike 3.0 Unported.

Todo o conteúdo deste capítulo, exceto quando houver ressalva, é publicado sob a licença Creative Commons Atribuição Uso Não Comercial - Partilha nos Mesmos Termos 3.0 Não adaptada.

Todo el contenido de este capítulo, excepto donde se indique lo contrario, está bajo licencia de la licencia Creative Commons Reconocimento-NoComercial-CompartirIgual 3.0 Unported. 


\author{
Mary Jane Spink
}

\title{
Linguagem e produção de sentidos no cotidiano
}

Esta publicação é parte da Biblioteca Virtual de Ciências Humanas do Centro Edelstein de Pesquisas Sociais - www.bvce.org

Copyright (c) 2010, Mary Jane Spink

Copyright (c) 2010 desta edição on-line: Centro Edelstein de Pesquisas Sociais Ano da última edição: 2004

Nenhuma parte desta publicação pode ser reproduzida ou transmitida por qualquer meio de comunicação para uso comercial sem a permissão escrita dos proprietários dos direitos autorais. A publicação ou partes dela podem ser reproduzidas para propósito não comercial na medida em que a origem da publicação, assim como seus autores, seja reconhecida.

ISBN 978-85-7982-046-5

Centro Edelstein de Pesquisas Sociais

www.centroedelstein.org.br

Rua Visconde de Pirajá, 330/1205

Ipanema - Rio de Janeiro - RJ

CEP: 22410-000. Brasil

Contato: bvce@centroedelstein.org.br 


\section{SUMÁRIO}

\section{Apresentação}

Prefácio

\section{Capítulo I}

\section{O conhecimento como construção social} ...1

1. Modernidade tardia e a reflexividade em ciência....

2. A perspectiva construcionista

3. Ilustrando a postura construcionista em pesquisa

\section{Capítulo II}

A produção de sentidos na perspectiva da linguagem em ação........26

1. O foco nos Repertórios Linguísticos .........................................28

2. A linguagem e os processos de interanimação dialógica................34

3. Posicionamento: a produção discursiva de selves...........................36

\section{Capítulo III}

\section{As múltiplas faces da pesquisa sobre produção de sentidos no} cotidiano

1. Os mapas, as árvores de associação e as linhas narrativas .............38

2. Trabalhando com repertórios linguísticos

3. Por uma visão caleidoscópica da linguagem em ação: as conversas do cotidiano

\section{Capítulo IV}

Dúvidas e questões dos participantes do curso

Referências

\section{APRESENTAÇÃO}

Uma das principais qualidades de um livro é servir de apoio ao estudante e ao pesquisador na compreensão de questões que os mobilizem nas suas trajetórias de construção de conhecimento e dar visibilidade à produção teórica construída no Programa de Pós-Graduação em Psicologia da PUCRS. Contudo, especialmente no meio acadêmico, existem outras instâncias de produção destes conhecimentos, como por exemplo, grupos de discussão e pesquisa, seminários, encontros científicos e cursos de extensão. Estes espaços tendem a ser restritos a públicos específicos, tornando-se o acesso a esta produção um privilégio de um universo delimitado de pessoas. Buscando um espaço de interlocução destes saberes e com o intuito de promover diálogos com outras linhas de pesquisa, áreas de conhecimento, o Grupo de Pesquisa Estudos Culturais, Identidades/ Diferenças e Teorias Contemporâneas coordenou uma jornada de estudos que reuniu pesquisadores e teóricos de reconhecimento nacional e que estão em atividade e desenvolvimento de suas pesquisas. " Para que estes diálogos não se perdessem surgiu a ideia de democratizá-los por meio de uma série de publicações.

A intenção é que os textos possam dialogar com a perspectiva epistemológica do Grupo de Pesquisa Estudos Culturais, Identidades/ Diferenças e Teorias Contemporâneas, dando conta, de forma crítica e compromissada, de questões relevantes para a Psicologia Social e dos estudos que a partir dela se desenvolvem. Reflexão e produção de conhecimento sobre temas que compõem discussões contemporâneas, como processos de subjetivação, políticas de identidade, esferas pública e privada, práticas discursivas, entre outros são os eixos principais deste material que ora apresentamos. A partir daí é possível encetarmos a problematização de alguns impasses crescentes da nossa cultura, investigando o posicionamento e a compreensão de autores a respeito de tópicos específicos sobre estas matérias e seus desdobramentos na vida cotidiana.

Esta produção aqui apresentada na forma de uma Coleção, intitulada Temas Contemporâneos em Psicologia Social, abordará temas como ética,

* O curso sobre Construcionismo Social: Abordagens Teóricas e Metodológicas foi ministrado no Programa de Pós-Graduação em Psicologia da PUCRS, 01 a 03 de agosto de 2000. 
metodologia de pesquisa, epistemologia e discussões teóricas sobre a compreensão do que vem a ser o social e o sujeito contemporâneo. Apesar de emergir de um campo de produção da Psicologia Social, as reflexões contempladas transcendem esta área específica de atuação, uma vez em que foram produzidas por pesquisadores oriundos de campos distintos como a Educação, Psicologia e Ciências Políticas, que por sua vez, também contribuem para o fomento do debate interdisciplinar.

Além disso, criamos uma seção chamada Tirando dúvidas, onde os alunos que participaram dos cursos fazem perguntas ao ministrante. Com isso, esperamos ajudar aqueles que se aventuram por esta metodologia a seguir preceitos defendidos pelos autores para que a pesquisa acadêmica conquiste ainda mais credibilidade: o rigor metodológico, entendido, na perspectiva construcionista, como a possibilidade de explicitar os passos de análise e da interpretação de modo a propiciar o diálogo frutífero e construtor de novas possibilidades de pensar o mundo.

\section{Porto Alegre, 26 de fevereiro de 2003.}

Neuza Maria de Fátima Guareschi Coordenadora do Grupo de Pesquisa Estudos Culturais, Identidade/Diferença e Teorias Contemporâneas. Professora do PPGP,

Faculdade de Psicologia-PUCRS.

\section{PREFÁCIO}

É com prazer que tomo a tarefa de apresentar este livro produzido a partir do curso ministrado pela Professora Doutora Mary Jane Spink, na Pontifícia Universidade Católica do Rio Grande do Sul, intitulado Linguagem e Produção de Sentidos no Cotidiano. Ela aborda diversos temas importantes para a Psicologia Social, desde a problematização dos sentidos produzidos no cotidiano até sua relação com a pesquisa acadêmica. Aponta que, a partir da análise das práticas discursivas e dos operadores que as objetivam, passamos a compreender o sentido como um fenômeno sociolinguístico, uma construção social, coletiva e interativa. Além disso, discute temas e conceitos como modernidade tardia e a reflexividade em ciência, a perspectiva construcionista e linguagem e os processos de interanimação dialógica. Por meio da linguagem, o Construcionismo Social incorpora, em parte, a perspectiva linguística do estruturalismo e a discussão das práticas discursivas e de discurso do pós-estruturalismo nas análises sobre a produção de sentidos no cotidiano dentro de sua abordagem teórico-metodológica.

Assim, esta produção assume especial importância para a Psicologia Social, por incluir em seu corpo teórico e metodológico o referencial das práticas discursivas e a produção de sentidos no cotidiano. É importante salientar que o Construcionismo Social inicia na Psicologia Social uma virada linguística, onde a linguagem não apenas explica a realidade, mas a constitui. Essa visão concebe sujeito e objeto como construções históricosociais, estabelece uma crítica à ideia representacionista do conhecimento e da objetividade, problematizando aspectos sobre a realidade e o sujeito.

O mundo humano não é constituído exclusivamente pela teia simbólica do universo linguístico, mas, segundo o Construcionismo não é possível utilizarmos uma "metalinguagem", ou seja: como podemos sair do universo linguístico para verificar a construção de sentido que fazemos acerca do real. Se não o podemos, o real, por conseguinte, apresenta uma materialidade, mas não uma materialidade mediada pela representação, em seu sentido clássico reflexionista, nem da tradição filosófica/reflexiva. Nesta, a representação reflete o objeto, que está no mundo. Há uma realidade estabelecida fora de nossa experiência de significação, mecânico e 
funcionalista, ao qual simplesmente deveríamos desenvolver metodologias adequadas para entendê-lo.

A perspectiva de fazer pesquisa apresentada por Mary Jane baseia-se no estudo do saber cotidiano, focalizando as maneiras pelas quais as pessoas produzem sentidos e posicionam-se nas relações sociais, no locus onde se produzem e se significam determinadas práticas e com a preocupação de desnaturalizar as construções do cotidiano. Ao não considerá-las como objetos naturais e permanentes - e sim como objetos construídos e transitivos - posiciona-se de forma precisa e específica para desenvolver métodos próprios de investigação da ação do pesquisador na sua relação com chamado campo de pesquisa.

Na perspectiva construcionista, a produção de sentidos traz consigo três aspectos que se fazem centrais para sua compreensão. Constitui-se como uma reação ao representacionismo, ou seja, à compreensão da possibilidade da ciência espelhar a realidade. Procura uma desconstrução da retórica da verdade e o empowerment de grupos socialmente marginalizados.

Com a certeza de que a leitura deste texto irá oportunizar debates importantes para o campo da Psicologia Social, fizemos questão de preservar seu caráter coloquial para que o leitor possa sentir a força das colocações de Mary Jane Spink e dos questionamentos profundos que levanta. Boa leitura.

Neuza Maria de Fátima Guareschi

\section{CAPÍTULO I}

\section{O CONHECIMENTO COMO CONSTRUÇÃO SOCIAL}

De modo a situar a perspectiva construcionista vou abordar três tópicos. Em primeiro lugar, penso ser necessário situar o debate sobre a Modernidade Tardia, sendo preciso, para tal, conceituar Modernidade Tardia, Sociedade de Risco e a aceitação recente da Reflexividade sobre a ciência. Essa é a base necessária para entender o construcionismo como posicionamento perante a produção de conhecimentos.

Em segundo lugar, vou situar o Construcionismo Social como movimento de contestação à ortodoxia em ciência e, num terceiro momento, falarei do Construcionismo na Psicologia, apresentando as posições de Kenneth Gergen e Tomás Ibáñes. Falarei, também, de um autor ainda pouco conhecido nos meios acadêmicos brasileiros que traz contribuições importantes para uma visão crítica da pesquisa de cunho construcionista: Ian Hacking.

\section{Modernidade tardia e a reflexividade em ciência}

Não é possível entender (e muito menos simpatizar com) o Construcionismo sem compreender por que muitos autores afirmam que a ciência tornou-se reflexiva. De forma semelhante, não é possível compreender o debate sobre Reflexividade em ciência sem entender que mundo é esse em que vivemos hoje. Uso o termo Modernidade Tardia para me referir ao que Ulrich Beck (1993) chama de Modernidade Reflexiva e outros autores chamam de pós-modernidade.

Minha opção pelo termo Modernidade Tardia deve-se ao fato de achar muito difícil nomear os nossos tempos atuais de pós-modernidade: o que viria depois da pós-modernidade? "Pós-pós-modernidade", "pós" ao terceiro grau? Entretanto, a despeito das diferenças de nomenclatura, o que parece estar sendo pontuado por diversos autores é que houve uma ruptura, a passagem de uma sociedade feudal para um outro tipo de formação social que define um novo período histórico - a modernidade - e que, de alguma forma, aquilo que marcava essa evolução, o período que muitos denominam como modernidade clássica, está atualmente em transformação. 
Se há um certo grau de concordância quanto à percepção desse movimento de ruptura com aquilo que instituiu a modernidade clássica, certamente não há concordância quanto à forma de referir-se ao seu produto. Por enquanto, prefiro usar o termo Modernidade Tardia, acatando que, de alguma forma ou outra, estamos ainda em um mesmo processo. Não há uma ruptura tão nítida, tão clara (pelo menos vista "de dentro" desse processo) como na transição do feudalismo para a sociedade moderna, marcada pela emergência dos Estados-nação e pelo capitalismo contemporâneo. Daqui a cinquenta anos, cem anos, quem sabe? As pessoas olharão para trás e dirão: puxa vida! Ninguém percebeu os sinais de ruptura!

Pedindo desculpas antecipadas pelo uso que farei de analogias associadas às recentes pesquisas na área da genômica durante este curso, essas rupturas nas formações sociais, a exemplo do que acontece na evolução genética, são coisas lentas; não se dão do dia para a noite. Então, é difícil você viver a ruptura e dizer que está havendo uma ruptura. Daí minha opção pelo termo Modernidade Tardia, pelo menos por enquanto.

Ulrich Beck é meu principal autor de referência para trabalhar essas questões. Não ele sozinho; há uma constelação de autores preocupados com o tema da modernidade, incluindo aí Giddens (1998) na Inglaterra; Vattimo (1996); Boaventura Santos (2000) em Portugal. Ou seja, há vários autores que estão trabalhando essa problemática. Não vou fazer uma contraposição entre esses autores, até porque o tema deste tópico não é Modernidade Tardia, e sim o Construcionismo como opção para falar de conhecimento.

De acordo com Beck, a Modernidade Tardia, que ele chama de Modernidade Reflexiva, passa por três estágios de desenvolvimento: a PréModernidade, que corresponde à transição do feudalismo para a sociedade moderna; a Modernidade Clássica que é coexistente com a sociedade industrial e a Modernidade Tardia que é coexistente com a sociedade de risco.

O que Beck busca apontar é que na transição para a Modernidade Reflexiva muda o foco da preocupação no governo das populações. A Modernidade Clássica (ou sociedade industrial) é uma sociedade que se pauta, sobretudo, pela distribuição de bens. Por isso mesmo o paradigma da sociedade industrial é o Estado do bem-estar social. A distribuição de bens vem na cola do movimento que vai definir direitos de cidadania e direitos humanos e que tem repercussões na educação e na saúde entre outras áreas.

Hoje em dia, entretanto, segundo Beck, o que está em pauta é o controle dos riscos; ou seja, a distribuição dos males. Muitos autores que trabalham o tema da pós-modernidade têm uma posição bastante negativa acerca desse estado de coisas; têm uma certa tendência a olhar para isso tudo e dizer: "Meu Deus o que vai acontecer! Daqui a pouco as pessoas estarão fazendo clonagem em seres humanos ou estarão manipulando as células humanas, as células de animais, as células do trigo e estaremos caminhando para um futuro catastrófico". A ótica da sociedade de risco tende a ser bastante negativa, mas não precisa ser. Recentemente tive oportunidade de ouvir uma conferência de Boaventura Santos onde ele pleiteava a possibilidade de uma globalização positivada, por exemplo, pela possibilidade de resistência em rede. $\mathrm{O}$ fato é que pelas características da sociedade atual, nós temos sim uma problemática bastante importante que é essa questão de distribuição ou minimização dos riscos: o que fazer com os riscos que nós mesmos produzimos com o desenvolvimento da ciência e da tecnologia? É uma questão instigante que venho abordando em uma das linhas de pesquisa que venho desenvolvendo (Spink, 2000).

Beck propõe que a Modernidade sempre implica ruptura com a tradição. Por exemplo, há uma série de estruturações das relações sociais que eram próprias da sociedade feudal e que a modernidade veio romper. Mas nunca chega a ser uma ruptura total. Há permanências que ficam óbvias, por exemplo, na pesquisa de tempo longo de repertórios linguísticos. Beck trabalha essa temática de uma forma muito interessante. Ele afirma que para que a sociedade capitalista pudesse ter sucesso, foi preciso incorporar alguns aspectos do feudalismo no seio da sociedade capitalista.

Para ele, a família é um exemplo de estrutura que incorpora aspectos da sociabilidade feudal, tornando-se um núcleo feudal dentro de uma sociedade que se pauta pela igualdade, fraternidade e liberdade. Por que feudal? Pela distribuição de papéis entre homens e mulheres, que mantém a mulher numa situação de servidão. Obviamente Beck se refere à família prototípica da modernidade clássica, da sociedade industrial. Até certo ponto isso ainda permanece hoje, mas também se observam transformações importantes na estrutura familiar. 
A Modernidade Reflexiva, segundo Beck, gera uma série de desmistificações, entre elas: a desmistificação da ciência e a desmistificação dos modos de ser na sociedade. A desmistificação da ciência implica dois movimentos paralelos: o questionamento das bases do conhecimento no plano da epistemologia - que remete à questão da ciência reflexiva - e o questionamento dos produtos da ciência - que remete à questão da gestão dos riscos. O debate sobre alimentos transgênicos é exemplo de ambos os movimentos. Parece que o Rio Grande do Sul tem uma posição crítica aos transgênicos. Já a Argentina, vizinha, tem outra completamente diferente, sendo muito mais positiva em relação aos transgênicos.

O exemplo é interessante, pois ilustra bem a posição de Beck sobre Reflexividade em ciência: a questão epistemológica é um questionamento que se dá dentro da própria ciência, já o questionamento a respeito dos produtos da ciência é um movimento social que se dá também fora da ciência. Assim, hoje há um site na Internet que se chama "cientistas preocupados com a genética" e é alimentado por discussões e informações vindas de cientistas que falam a partir da visão "de dentro" da ciência. Mas encontramos também sites de ativistas leigos, pessoas que não são cientistas ou pelo menos não estão falando a partir da posição de cientistas, também se posicionando a respeito dos riscos nessa área da engenharia genética.

Quais então as características da Modernidade Tardia que são fundamentais para o argumento construcionista? Beck arrola uma série de características dentre as quais três parecem-nos fundamentais para entender o debate moderno sobre ciência: globalização, individualização e Reflexividade.

Globalização é um termo que está muito em voga e que já foi incorporado ao vocabulário do cotidiano. Buscando situá-la para além da associação estreita com capitalismo tardio, proporíamos adotar a definição dada por Giddens (1998): globalização sendo a intersecção da ausência e presença ou, o entrelaçamento de relações sociais e eventos sociais que estão distantes dos contextos locais.

A face mais visível desse processo de globalização é a mídia eletrônica. São as comunicações em tempo real: o telefone, o ICQ da Internet que possibilitam a interação à distância, modificando, entre outras coisas as relações de trabalho. Esse processo de "eletronificação" da vida cotidiana foi incrivelmente rápido. Maria José Tonnelli defendeu sua Tese de Doutorado em 2000 sobre a temática da aceleração da vida cotidiana no trabalho (Tonnelli, 2000). Nessa pesquisa ela entrevistou várias pessoas: diretores de empresa, gerentes, copeiras e faxineiras. Ela entrevistou uma dessas pessoas duas vezes com intervalo de um ano. No decorrer desse ano, o que mudou na vida dessa mulher? Há um ano ela mal dominava as novas tecnologias de comunicação. Hoje, ela viaja frequentemente, sempre levando seu laptop, "plugada" na Internet, com um celular, dois, três, quantos celulares forem possíveis. Quando em São Paulo, ela fala diariamente, com alguém na China, no Chile, no Canadá, seja lá onde estiver seu interlocutor. Ela não consegue mais pensar o trabalho sem essas vinculações, essa rede eletrônica.

Sem dúvida alguma, a globalização pensada na ótica da comunicação e informação traz mudanças nas formas como as pessoas se relacionam. Há dois anos, quantos de vocês tinham telefones celulares? Em 1998, com certeza contava-se nos dedos os donos de celulares. Eram sinais de prestígio e as pessoas faziam deles um "espetáculo": no restaurante, colocavam seus celulares em cima da mesa, deixavam tocar para que todos vissem que possuíam um telefone celular. Hoje em dia, o guarda noturno que cuida da rua onde moro tem um celular, e acho ótimo que ele tenha: passou a ser uma estratégia de segurança numa cidade intensamente insegura!

Muito embora a rapidez com que se deu essa reticulação eletrônica impressione, são os processos de individualização que são talvez a característica mais marcante da modernidade tardia. A individualização está profundamente imbricada com os processos de destradicionalização. Afirmei anteriormente que a mudança sempre resulta numa ruptura com a tradição. Destradicionalização é exatamente o termo que dá cor e conteúdo a esse argumento. Estamos falando da destradicionalização das principais instituições da modernidade clássica: família, trabalho, educação. É isso que faz com que as biografias se tornem, também elas, reflexivas (ou autorreferidas). Em resposta à pergunta "quem é você", já foi usual referir aos laços institucionais: eu trabalho na Ford; eu sou metalúrgico. Hoje em dia não, as pessoas escolhem os elementos da sua biografia que mais se adaptam à situação. Há uma consciência aguda da multiplicidade de selves disponíveis para apresentação pública (Harré, 1998).

A destradicionalização no âmbito do trabalho refere-se às novas modalidades de vinculação ao mundo do trabalho: o subemprego, o 
desemprego em massa, a terceirização do trabalho, às formas de trabalho que não estão mais localizadas em instituições. Até mesmo as que têm um vínculo formal com uma instituição começam a ter a opção de trabalhar em casa. Aqui, em Porto Alegre, talvez a locomoção não seja tão problemática, mas em São Paulo está levando tanto tempo para ir de A para B que compensa pagar para as pessoas trabalharem em casa. Em outros países do mundo, isso está acontecendo com muita velocidade. É evidente que isto muda tremendamente as relações de trabalho. Que implicações isso terá para o futuro? Para o envelhecimento? Para a família? A destradicionalização do trabalho é um campo aberto ao estudo na área da Psicologia Social.

Também a família está sendo destradicionalizada. Anteriormente referi-me à família como o núcleo feudal da sociedade industrial. Mas hoje sabemos que não basta abrir a porta e dizer para as mulheres: saiam para trabalhar! Isso não destrói necessariamente o que Beck refere como núcleo feudal da modernidade clássica. Gera as duplas jornadas, as triplas jornadas, mas cria novas possibilidades de sobrevivência que são menos vinculadas e dependentes do homem.

Essa nova sensibilidade para a autonomia certamente se faz presente na vida cotidiana. Ontem, creio que na MTV, ouvi uma música da Annie Lennox: um elogio às mulheres e à sua nova independência. A música tinha por refrão a frase: "nós não dependemos mais de vocês, embora isso não quer dizer que não gostamos de vocês". Ou seja, não por isso vamos todas virar lésbicas. Não é isso, mas o fato de ter uma certa independência econômica, o fato de ter uma autoestima mais alta faz com que as relações de gênero também se modifiquem.

A destradicionalização da família tem também outras dimensões e aqui retomo o exemplo do genoma. Quantos de nós já escutamos falar (ou lemos sobre) de fulano que congelou o esperma de modo a escolher o momento da paternidade sem os riscos do envelhecimento. Congelado, o esperma estará "novinho" para quando quiser reproduzir; no momento em que for conveniente. Há mulheres que estão engravidando após a menopausa; há combinações inusitadas de reprodução assistida, e daí por diante. São novos desenvolvimentos vinculados à engenharia genética que, inevitavelmente, começam a transformar esse resíduo feudal da Modernidade Clássica; a destradicionalizar também a família.
E a educação? A educação passou a ser um contraponto na vida, da geração à morte. Começamos a estender a linha de tempo educativa com as teorias sobre educação in utero: tocar música erudita para que a criança nasça com gosto pela música. Ler Shakespeare, ou ler Erico Veríssimo em voz alta para que a criança desenvolva o gosto pela boa literatura. A criança mal nasce e todos se põem a falar inglês para que seja bilíngue, e daí por diante.

Quando fiz o doutorado, essa era a titulação máxima da carreira. Hoje em dia não: faz-se pós-doutorado, estágios seniores e um sem-número de cursos de especialização. A educação passou a ser um empreendimento contínuo: começa antes de nascer e adentra pela "terceira idade". Imagino que aqui na PUCRS também há cursos para a terceira idade. Na PUC de São Paulo esse parece ser um campo em expansão.

A educação antes era baseada no livro texto. Hoje em dia, a moçada vai para a Internet em busca de informação. A tradicional enciclopédia morreu: passou primeiro para CD-ROM e creio que hoje nem isso. Você navega por um mar de informação (nem sempre com cartas náuticas adequadas) em busca da informação que você quer. Isso muda a natureza da relação educativa assim como mudam os instrumentos de educação. Tudo isso faz parte desse processo mais amplo de individualização.

A terceira característica da Modernidade Tardia destacada por Beck é a Reflexividade, e esta é a ponte para falar do Construcionismo. De forma sucinta podemos dizer que a Reflexividade é a abertura à revisão crônica das práticas instituídas à luz de novas informações. Em suma, significa que temos liberdade, e não só a liberdade, mas até a necessidade (decorrente desse processo de educação continuada) de rever conceitos e de propor novos conceitos.

A Reflexividade tem dupla face: de um lado é uma atitude intrínseca à própria ciência que começa a olhar para si mesma e a quebrar certas hegemonias. Abre-se, por exemplo, o debate metodológico. É imperativo haver método único para todas as ciências? É possível falar de uma dicotomia entre ciências naturais e ciências sociais? Qual a especificidade e lugar dos métodos qualitativos? Só a quantidade pode ser a medida do avanço conceitual? São todas elas perguntas que servem de indícios desse debate maior que coloca em xeque o que Ibáñez (1991) denominou de 'retórica da verdade'. 
Desde Galileu adotamos o método experimental como parâmetro de 'boa ciência'. Mas aos poucos acirrou-se um movimento de contestação e questionamento sobre os caminhos seguros para chegar às verdades últimas. Coloca-se no rol da discussão o debate sobre a natureza do conhecimento.

Mais recentemente, na Sociologia e na Filosofia da Ciência, acirra-se esse debate. Por exemplo, Ludwick Fleck (1979), que escreve sua obra sobre a construção do conceito médico de sífilis nos anos 30; ou ainda Thomas Kuhn (1962), que publica nos anos 60 sua influente obra A Estrutura das Revoluções Científicas. E atualmente contamos com Bruno Latour (1987), Steve Woolgar (1988), Karin Knorr-Cetina (1981) e outros tantos autores que, trabalhando de dentro da ciência, buscam entender a ciência como prática social, incluindo aí os processos de legitimação de conhecimento.

Mas a Reflexividade emerge também 'de fora' da ciência, a partir da crítica aos produtos da ciência. Esse segundo movimento da Reflexividade na arena da ciência tem um papel importante na emergência da preocupação com as questões éticas da pesquisa. Por muito tempo tivemos uma ciência desenvolvida como prática ensimesmada, uma prática que não abria as portas do laboratório à inspeção pública. Bastava entregar ao público o resultado final da pesquisa: um novo medicamento, uma nova vacina, uma nova tecnologia.

Hoje em dia todos esses processos estão abertos à inspeção. Por quê? Em parte, porque a própria evolução da noção de direitos assim o exige, mas também porque as tecnologias da informação tornam disponíveis essas informações. Se hoje acontece uma conferência sobre desenvolvimento de vacinas de AIDS, no dia seguinte, estará sendo discutida na Internet. É muito difícil fazer ciência de portas fechadas. Não só pela exposição na mídia; há ainda os diversos órgãos de regulação dos produtos da ciência, como o FDA nos EUA que controla como esses medicamentos chegam ao mercado, ou as instâncias de controle da pesquisa, os comitês de ética nas instituições de pesquisa, nas universidades e nos próprios laboratórios, que cuidam dos protocolos de pesquisa e dos aspectos éticos desses protocolos.

Essa questão da ética dos procedimentos de pesquisa acompanha a questão da Reflexividade não tanto de 'dentro' da ciência, mas certamente nas fronteiras entre a ciência e a sociedade civil. Creio que era isso o que queria trazer como pano de fundo, como contexto, para entrar no segundo tópico desta aula, mais diretamente relacionado com a perspectiva construcionista.

\section{A perspectiva construcionista}

Para apresentar a perspectiva construcionista creio ser importante começar situando o que as pessoas estão chamando de construcionismo. Na Psicologia, um dos autores mais antigos nessa discussão é Kenneth Gergen. Já em 1985 Gergen havia publicado um texto intitulado O Movimento Construcionista Social na Psicologia Moderna que, publicado no American Psychology, se tornou clássico como texto introdutório à postura construcionista na Psicologia. Se Gergen se referia, em 1985, ao movimento construcionista, é evidente que a reflexão construcionista já estava em pleno andamento.

Nesse texto Gergen afirma que "a investigação construcionista preocupa-se com a explicitação dos processos por meio dos quais as pessoas descrevem e explicam o mundo em que vivem" (Gergen, 1985). Ou seja, de uma forma ou outra, essa discussão enquadra-se no âmbito de uma teoria do conhecimento. Enquadra-se ou contrapõe-se, pois a perspectiva construcionista, como aponta Gergen já nesse texto, traz no seu bojo várias implicações para a maneira como entendemos "conhecimento".

Implica, primeiramente, abdicar da visão representacionista de conhecimento que toma a mente como o espelho do mundo. Um dos autores que muitos de nós usamos para trabalhar isso é Richard Rorty e especialmente o livro Filosofia e o Espelho da Natureza, publicado originalmente em 1979. Um alerta: ao referirmo-nos à visão representacionista do conhecimento, não estamos falando da teoria psicossocial das Representações Sociais. Estamos falando de uma maneira de entender o conhecimento que se inaugura na modernidade clássica.

Em segundo lugar, implica adotar a perspectiva de que conhecimento é algo que as pessoas fazem juntas. Consequentemente, resulta numa socialização do conhecimento que passa a ser algo que construímos juntos por meio de nossas práticas sociais e não algo que apreendo do mundo. Talvez seja por isso que essa vertente do conhecimento suscita tanto interesse na Psicologia Social, pois se trata fundamentalmente de uma teoria social do conhecimento. 
Também Thomas Ibáñes, traz contribuições relevantes para entender o que seria uma Psicologia Social de cunho construcionista. Em 1994 Ibáñes publicou, na revista da Associação Venezuelana de Psicologia Social, um texto introdutório ao Construcionismo que tem o mérito de ser excepcionalmente claro e sintético. Nesse texto, ele vai propor que são necessárias várias desconstruções de modo a adotar uma postura construcionista plena.

Em se tratando de uma forma de entender o "conhecimento", a primeira desconstrução necessária é da dicotomia sujeito-objeto. Ibáñes afirma que na inversão construcionista tanto o objeto como o sujeito são tomados como construções sociais. Sendo o conhecimento uma construção social, é o conhecimento socialmente produzido que constrói ambos, o sujeito e o objeto. Ibáñes segue nesse processo de desconstrução focalizando quatro pressupostos básicos da atividade científica: os pressupostos ontológicos, epistemológicos, metodológicos e sobre a natureza humana. No que se refere aos pressupostos ontológicos, Ibáñes aponta que na postura construcionista não existem objetos naturais: os objetos são como são porque nós somos como somos. Essa é uma questão complexa que implica o posicionamento sobre a natureza da realidade e que será abordada mais tarde neste curso. Mas por ora basta frisar que, para o Construcionismo (pelo menos na vertente discutida por Ibáñes, pois há muitos Construcionismos!), não há objetos independentes de nós e nem existimos independentemente dos objetos que criamos. Essa questão da objetivação dos fatos sociais foi muito bem trabalhada por Peter Berger e Thomas Luckmann no livro A Construção Social da Realidade (1976).

Quanto aos pressupostos epistemológicos, para o Construcionismo o conhecimento não representa a realidade: não é possível distinguir entre a nossa inteligência sobre o mundo e o mundo como tal. Mais uma vez, essa questão é bastante complicada: é difícil afirmar que existe ou não um mundo material para além de nossas produções culturais, pois não conseguimos distinguir entre esse mundo e o nosso conhecimento sobre o mundo. Espero que a discussão que farei a seguir sobre o trabalho de Thomas Laqueur sobre a invenção do sexo possa dar um pouco mais de substância a essa afirmação.

Quanto aos pressupostos sobre a natureza humana, na perspectiva construcionista o conhecimento é tomado como prática social, ou seja, os objetos e critérios de verdade são produções sociais que se institucionalizaram por meio de processos de habituação (ver, por exemplo, Berger e Luckmann, 1976).

Finalmente, no que diz respeito aos pressupostos metodológicos, o Construcionismo traz para a pesquisa uma postura desreificante, desnaturalizante, desessencializadora que radicaliza ao máximo a natureza social do nosso mundo vivido e a historicidade de nossas práticas. Em suma, Ibáñes propõe que o que tomamos como objetos naturais são objetivações decorrentes de nossas construções, de nossas práticas. Essa é uma proposição compartilhada por muitos autores. Portanto, não estou aqui afirmando que Ibáñes é quem melhor expressa tais posições; trago-o como uma voz entre outras tantas porque compartilho certas de suas posições. Mas reitero que essas posições têm ressonâncias com a de outros autores.

Frequentemente as pessoas perguntam se Construcionismo e Construtivismo são a mesma coisa. É possível desfazer essa dúvida a partir da própria Psicologia, mas, até porque o Construcionismo não é um movimento intrínseco à Psicologia, vou pontuar a diferença a partir da Filosofia e, mais particularmente, de um filósofo analítico: Ian Hacking. Embora ele não se autodenomine construcionista, sua obra recente, intitulada The Social Construction of What?, é um livro sobre Construcionismo Social.

Hacking afirma que a noção de construção é uma noção basicamente Kantiana e conclui, em sua discussão sobre a noção, que nós não conseguimos nos libertar nem de Platão nem de Kant. A noção de construção, presente em Platão e em Kant, tem três grupos de herdeiros na Filosofia contemporânea. O primeiro grupo é formado pelos construcionalistas, termo cunhado por Goodman para falar dos mundos que nós criamos. O projeto construcionalista tem por objetivo demonstrar que várias entidades, conceitos e palavras são construídas a partir de outros materiais. Mas os construcionalistas não estudam a história e nem os eventos sociais. Eles estão interessados na construção lógica.

$\mathrm{O}$ segundo grupo de filósofos que usam uma palavra associada à construção - os Construtivistas - refletem a partir da Matemática. Eles propõem que, em certo sentido, os objetos da matemática, números e fatos matemáticos, são socialmente construídos. Para Hacking, o Construtivismo é expressão muito particular dessa vertente da Filosofia da Matemática. 
Já o Construcionismo designa os vários projetos históricos, sociológicos, filosóficos que têm por objetivo demonstrar ou analisar interações sociais historicamente situadas ou os caminhos que levaram ao estabelecimento de algum fato ou entidade do presente.

Essas distinções foram feitas por Hacking a partir de uma leitura interna à Filosofia. Vale lembrar que, no âmbito da Psicologia, a confusão mais comum é entre Construcionismo e Construtivismo, palavras que têm associações teóricas bastante diversas. Tendo a reservar Construtivismo para uma vertente de estudos psicológicos baseados no desenvolvimento da cognição, pautada principalmente nas teorizações de Piaget. Embora aceitando a atividade do sujeito na cognição, essa vertente parece continuar acatando a dicotomia de sujeito e objeto. Hacking vai concluir que, para todas estas variedades de "construção" - construcionalistas, construtivistas, construcionistas - as coisas não são o que parecem ser. Todos propõem questionar o verniz da realidade ou daquilo que as pessoas tomam por real. A surpresa, conclui ele, é que todos se movem ainda na dicotomia entre a aparência e realidade (ou essência) que foi introduzida por Platão e que recebe sua forma definitiva em Kant. Quais são as possíveis soluções deste dilema?

Aqui a confusão é grande para quem não é filósofo! Há vários autores na Psicologia que buscam apoio no naturalismo crítico de Roy Baskar (1983) para quem o dilema construcionista pode ser resolvido pela distinção entre duas posturas complementares: o realismo ontológico e o construcionismo epistemológico. Ou seja, a existência de um mundo real (realismo ontológico) não é colocada em dúvida, mas o conhecimento é tomado como uma construção social (construcionismo epistemológico). Essa é uma possibilidade de conciliação que tem tido bastante aceitação na Psicologia.

Já Hacking parece dar preferência à posição defendida por Searle, o qual, em seu livro intitulado A Construção Social da Realidade (que Hacking alerta nada tem a ver com construcionismo), argumenta que os fatos são ontologicamente subjetivos e epistemologicamente objetivos. Assim, os fatos seriam ontologicamente subjetivos quando dependem dos seres humanos e de suas práticas. Por exemplo, o aluguel de um apartamento existe porque existe uma prática social que institui tal aluguel. $\mathrm{O}$ aluguel não existiria se não existissem pessoas; se não existisse uma estrutura de propriedade que faz com que as pessoas aluguem propriedade. Entretanto, ele é epistemologicamente objetivo, porque está inserido numa realidade concreta: se você não pagar o aluguel, será despejado. Muito embora não tenha competência para aprofundar esse debate, acho que é importante sinalizar para sua existência e para a diversidade de soluções aí propostas. É também importante sensibilizar para o fato de que se trata de debate ainda em andamento porque, embora fale-se muito em epistemologia nos cursos de Psicologia, pouco aborda-se a questão da ontologia.

Retomando Ibáñes e as desconstruções necessárias para a adoção da postura construcionista, falamos até agora da dicotomia entre o sujeito e o objeto, e suas implicações em relação aos pressupostos sobre o mundo, o conhecimento, a natureza humana e a metodologia. A segunda desconstrução (inevitavelmente associada à primeira) é a da retórica da verdade. O termo "retórica da verdade" é usado por Ibáñes para se referir a um tipo de legitimação do conhecimento intrinsecamente associada ao método científico e que pressupõe a existência de uma verdade transcendental. Para o Construcionismo, entretanto, a verdade é a verdade de nossas concepções, de nossas instituições, de nossas relações, de nossos acordos sociais.

Essa postura é compartilhada por outros pensadores, por exemplo, Edgar Morin (1985). Vale alertar que embora esteja propondo que há semelhança na postura sobre a validação essencialmente social do conhecimento não estou afirmando que Morin é construcionista. Para Morin, o problema epistemológico da complexidade é a complexidade do problema da objetividade. Assim, para chegar à objetividade temos que percorrer um longo caminho que começa com a história e com a cultura, que definem a tradição crítica que é a legitimadora do que é verdade e do que é objetividade. Isso implica a aceitação das regras do jogo científico.

Aceitamos essas regras porque fazemos parte de uma comunidade de compartilhamentos e acordos, porque evidentemente existem conflitos entre teorias, ideologias e metafísicas. Também Pierre Bourdieu (1983) nos ajuda a refletir sobre essa sociabilidade intrínseca da produção de saberes legítimos a partir da noção de campo científico. O que se pontua aí é que, de alguma forma, isso implica a aceitação das regras do jogo pela comunidade (no caso, a comunidade científica). Só que a comunidade somos nós; ou seja, esse processo de legitimação da objetividade implica 
relações interpessoais intersubjetivas: comunicação entre investigadores e provas obtidas de experimentos ou de relatos de observações. Trata-se de um longo percurso que envolve convenções e negociações e é, portanto, absolutamente social. Então, se tantos autores concordam que os fatos científicos são construções sociais, qual a especificidade da pesquisa construcionista? Trouxe Morin e Bourdieu como apoio para falar da desconstrução da retórica da verdade; entretanto, nem um nem outro se definiriam como construcionistas. Para situar a especificidade da pesquisa construcionista, retomo as reflexões de Hacking.

Hacking (como Danzinger, 1997) busca o compartilhamento na diversidade de posturas que podem ser encontradas nas reflexões construcionistas. Segundo o autor, o que parece unir as diferentes correntes construcionistas é o objetivo subjacente de libertação daquilo que se tornou instituído ou essencializado. Existiria, assim, um substrato crítico-político nas pesquisas construcionistas. Basicamente, a postura construcionista é crítica do status quo: parte-se da premissa que $\mathrm{X}$ (sendo $\mathrm{X}$ um fenômeno social qualquer) não precisaria ter existido ou ser como é; não é determinado pela natureza das coisas; não é inevitável. É essa premissa que distingue a pesquisa construcionista.

Muitos construcionistas não param nesta primeira constatação. Vão além afirmando que esse $X$ é intrinsecamente ruim; é negativo. Nesses casos há uma afirmação de valor explícita que pode levar ainda ao reconhecimento que estaríamos muito melhor se $\mathrm{X}$ não fosse assim. Em suma, embora toda a pesquisa construcionista parta do estranhamento daquilo que é familiar e socialmente instituído, pode ser desenvolvida com diferentes graus de compromisso. Hacking propõe seis graus de compromisso com a transformação social:

1. Histórico: quando o objetivo é fazer a história de $\mathrm{X}$ de modo a argumentar que $\mathrm{X}$ foi construído por meio de processos sociais que são históricos e culturalmente situados. O trabalho da primeira fase de Foucault - A História da Loucura, A História da Clínica, Vigiar e Punir - são pesquisas que se enquadram perfeitamente bem aí. Incluo aí pesquisadores que estão fazendo trabalhos arqueológicos sem necessariamente definirem-se como construcionistas, mas cujo trabalho tem afinidade com a postura construcionista.
Esse seria um primeiro grau de compromisso com a transformação social;

2. Irônico: quando reconhecemos que aquilo que tomamos como parte inevitável do mundo ou de nossa arquitetura conceitual, poderia ter sido substantivamente diferente. Trata-se do reconhecimento que $\mathrm{X}$ é altamente contingente, produto de forças sociais e históricas, mas algo que não podemos, no momento, deixar de tratar como parte do universo interacional ou material;

3. Reformista: quando tomamos uma posição frente a $\mathrm{X}$ : $\mathrm{X}$ é ruim! Embora aceitando que não seria possível viver sem $X$, busca-se, pelo menos, alterar alguns de seus aspectos de modo a minimizar seus efeitos nefastos;

4. Desmascarador: que busca também expor as funções extrateóricas de X;

5. Rebelde: que leva a sério a postura reformista e assume publicamente que estaríamos melhor sem X;

6. Revolucionário: que extrapola a esfera das ideias e busca ativamente mudar $\mathrm{X}$.

Segundo Hacking, para que a pesquisa construcionista seja útil é preciso que se tenha clareza sobre o que é que está sendo construído, que $\mathrm{X}$ é esse. O autor faz uma distinção interessante entre ideias e objetos que, embora complexa, inclui dois aspectos que merecem destaque. O primeiro é que o que está sendo construído na maior parte das vezes são ideias, mas são ideias que efetivamente acabam por definir o objeto. O segundo é que essas ideias não são construídas como ato de vontade; elas são subprodutos de uma matriz. É preciso que exista um conjunto de elementos, que ele chama de matriz, embora reconheça que este termo tem múltiplos significados e definições, para que algo possa ser construído. Em suma, não basta focalizar a evolução das ideias, é preciso entender como essa ideia emerge na matriz de eventos que é sua condição de possibilidade.

Para exemplificar o uso que faz da noção de matriz, Hacking discute a emergência da categoria "mulheres refugiadas políticas" no Canadá (um dos países que levou mais a sério as resoluções das Nações Unidas sobre 
refugiados). É evidente que a mulher concreta que fugiu de seu país por questões políticas e buscou refúgio em outro país não é uma construção social. Esse ato é produto de eventos sociais concretos que a levam a abandonar seu país. Mas para que ela possa entrar no Canadá, ela tem que receber o rótulo de "mulher refugiada política" caso contrário tem que entrar como imigrante, que é outro processo sendo mais complicado a longo prazo.

Para que ela receba esse rótulo, uma série de instituições e pessoas têm que ser envolvidas: advogados, ativistas de direitos humanos, imprensa, legislação específica, abrigos onde elas ficam enquanto o processo está correndo. Disso depende o seu status perante as autoridades da imigração: se imigrante, vamos devolvê-la; se não é imigrante, vamos respeitá-la porque é refugiada política.

Essa matriz engloba pessoas, instituições, formulários que têm que ser preenchidos, fotografias que têm que ser tiradas e passaportes. Há, assim, uma materialidade aí implicada que faz com que esse rótulo (essa ideia) efetivamente construa esse objeto - a mulher refugiada - que adquire certos direitos, ganha dinheiro, pode viver em certos lugares e daí por diante. Em suma, é importante ter clareza sobre o que (ideia ou objeto) está sendo construído nesse processo; é importante também, que se trabalhe de uma forma ampla, incluindo a matriz de elementos que dão sustento à ideia que está sendo construída.

A postura construcionista tende a suscitar objeções de duas ordens: o reducionismo linguístico e o relativismo. Quanto ao reducionismo linguístico, existe sem dúvida uma ênfase na linguagem. Muito embora ninguém que esteja afinado com a postura construcionista afirme que a linguagem é o único produto da atividade humana que gera objetivações, há, de fato, uma tendência a trabalhar com produções linguísticas.

Também o relativismo é um aspecto central do Construcionismo e não poderia deixar de ser porque, como afirma Hacking, afirmar que $X$ não precisaria ter existido (ou ter existido dessa forma) é uma precondição da pesquisa construcionista. Isso implica acatar um certo grau de culturalismo e de ceticismo perante aquilo que está socialmente instituído. Mas essas construções não são tomadas como atos da vontade de indivíduos; são produtos de interações sociais sustentados por matrizes complexas de instituições, pessoas e tecnologias de visibilidade. É preciso entender essas construções em seu contexto de produção: que sociedade é essa, que usos são feitos disso e que consequências têm. É difícil muitas vezes sairmos dessas construções e olhá-las de fora porque estamos habituados a elas e fomos socializados nessas matrizes. Mas a postura construcionista tem que ser relativista por princípio: não aceitando isso, não se está fazendo uma pesquisa construcionista.

Reconhecendo que a objeção ao relativismo da postura construcionista é corrente, Hacking pergunta por que o relativismo suscita tanto medo e, como resposta, explora algumas possibilidades. Um dos medos é que o relativismo passe a ser licença para toda e qualquer coisa. Já que tudo é construído, tudo vale. Há também o medo do revisionismo histórico, tal como aconteceu recentemente em relação aos campos de concentração e extermínio dos judeus. Há, ainda, o medo da perda da tradição.

Não há como negar esses medos. Mas as preocupações que suscitam abrem mais uma janela para reflexão ética. Para afirmar que $X$ não precisaria ter existido ou que $\mathrm{X}$ poderia ter sido diferente, tenho que me situar no campo da ética. Por isso, para mim, as coisas andam juntas. $\mathrm{O}$ relativismo suscita a necessidade da reflexão sobre os efeitos daquilo que a gente produz; suscita, portanto, uma reflexão ética. O mérito de acatar tão abertamente uma postura relativista face aos fatos sociais é que ela abre o debate; força a reflexão sobre os efeitos de nossas práticas em pesquisa. Há formas de pesquisa que escondem, escamoteiam esse debate. Prefiro o debate; prefiro lidar com os problemas que o relativismo possa suscitar.

\section{Ilustrando a postura construcionista em pesquisa}

Escolhi duas pesquisas que considero ilustrativas da postura construcionista. A primeira é de Thomas Laqueur, um historiador da Universidade da Califórnia que está falando justamente da ruptura que leva do feudalismo à modernidade clássica, a que me referia quando falava de modernidade tardia no início desta aula. Ele vai estudar transformações que ocorreram na forma de descrever sexo - biologicamente e anatomicamente - na Renascença e a partir do século XVIII.

Comecei a me apaixonar pelo livro lendo a introdução, onde ele contava que era um historiador da Medicina especializado no século XIX. 
Ele estava em Oxford, Inglaterra, fazendo uma pesquisa para um livro que ele pretendia escrever sobre a noção de ciclos de vida na Medicina do século XIX. Por acaso ele se deparou com manuais de parteiras do século XVII e descobriu, com total surpresa, que não apenas eles falavam em orgasmo feminino, mas o orgasmo feminino era tomado como condição sine qua non para engravidar. Lendo isso com o olhar de um historiador especializado em Medicina do século XIX, Laqueur estranhou tendo em vista que no século XIX questionava-se até mesmo a possibilidade da mulher ter orgasmo. Parecia-lhe estranho, portanto, que no século XVII as pessoas estivessem tomando como dado que o orgasmo feminino era possível e ainda o colocando como condição necessária para engravidar.

Fascinado, Laqueur partiu da premissa que, para que esse discurso fosse possível nessa época, uma outra visão de corpo, uma outra visão de anatomia sexual deveria estar em circulação. Mudou assim sua rota de pesquisa e passou a investigar o que mais tarde denominou de "invenção do sexo", propondo que, até o século XVIII, a forma de conceber a anatomia sexual era pautada por relações de gênero mais do que pelo sexo biológico.

Essa hipótese surpreende porque muitos de nós aprendemos que gênero é uma categoria inventada no século XIX. Mas Laqueur inverte essa relação; diz que para existir o gênero tal como ele é concebido hoje, foi preciso que se criasse o sexo, foi preciso que se criasse uma teoria de dismorfia sexual. Ou seja, até a Renascença, o que imperava na Europa era um modelo de sexo único. As descrições anatômicas descreviam os órgãos femininos como sendo idênticos aos órgãos masculinos só que invertidos, internalizados. A única diferença entre homem e mulher seria, assim, a externalização dos órgãos sexuais. Esse modelo tem seus antecedentes em Galeno, tendo sobrevivido, portanto, por um milênio resistindo às transformações sociais, culturais, históricas que ocorreram nesse período.

Para entender o modelo do sexo único, segundo Laqueur (1990: 25), temos que visualizar a genitália externa masculina voltada para dentro e estendendo-se internamente entre o reto e a bexiga. Se isto acontecesse, o saco escrotal necessariamente tomaria o lugar do útero, com os testículos localizados fora e de cada lado do útero. Nesta visão, o pênis passa a ser o cervix e a vagina; o prepúcio se torna a pudenda feminina, etc. Segundo Galeno, não encontraríamos uma única parte dos órgãos masculinos que simplesmente não pudesse mudar sua posição nesse processo de internalização.

Galeno, numa citação muito divulgada, compara os órgãos genitais femininos aos olhos de uma toupeira. Assim, os olhos da toupeira têm a mesma estrutura que os olhos dos outros animais, só que não permitem a visão; não se abrem, ficam imperfeitos. O mesmo ocorre com a genitália feminina. Ela não se abre e permanece uma versão imperfeita do que poderia ser se projetada para fora. Os olhos da toupeira são como os olhos de outros animais enquanto estão ainda dentro do útero. De forma semelhante, os órgãos femininos permanecem para todo o sempre como se estivessem ainda no útero: a vagina como um pênis que está eterna e precariamente por nascer; o ventre um saco escrotal atrofiado e daí por diante. Esses órgãos internos são sinais evidentes da falta de calor e, portanto, de menor perfeição. Diz Galeno (apud Laqueur, 1990:28) que "tal como o humano é o animal mais perfeito, assim, na humanidade, o homem é mais perfeito que a mulher, sendo a razão disso o excesso de calor, porque o calor é o principal instrumento da Natureza".

Esse modelo sobreviveu até o século XVIII talvez por ser compatível com a visão de mundo que predominou durante toda a Idade Média. Uma visão de mundo, onde a medida de todas as coisas era Deus, sendo o homem a medida das coisas na terra. Nesse sistema, a mulher não existia como categoria ontologicamente distinta. Essa visão de mundo gerou um tipo de ciência baseada em hierarquias de semelhanças sendo preciso romper com tal hierarquia para que outro modelo de ciência pudesse emergir.

Durante a Idade Média era muito difícil fazer dissecações. Embora essa prática existisse, não era bem vista pela Igreja; não era feita abertamente, não era legitimada. Mas na Renascença, a anatomia se tornou um símbolo do empiricismo nascente. Pensem nas diversas ilustrações renascentistas sobre dissecação constantes de quadros e tratados de anatomia: havia todo um teatro em volta da arte de dissecar. Nessa época a anatomia emerge como uma prática fundamental para o desenvolvimento da ciência médica. Muito embora as ilustrações renascentistas fossem semelhantes às modernas, a explicação do que se via pouco diferiu inicialmente do modelo de sexo único. 
Ou seja, "essa anatomia tão visual apenas demonstrou, com maior vigor, que a vagina era mesmo um pênis e o útero era o saco escrotal internalizado. Ver é acreditar ou, inversamente, acreditar é ver" (Spink, 1994a). Foi necessário que ocorressem mudanças no âmbito da ciência para que um outro olhar sobre o dado empírico se tornasse possível e foi necessário que ocorressem mudanças políticas e ideológicas para que o novo modelo do dismorfismo sexual, ou seja, de dois sexos incomensuráveis, pudesse prevalecer. Em suma, não bastou a evidência dos olhos. Foi preciso que mudassem certos elementos da matriz relacionados com o contexto político e, sobretudo com o contexto de interesses. Certamente, retomando a discussão de Beck sobre a modernidade clássica, o modelo de dismorfia sexual possibilitou a sobrevivência do feudalismo no núcleo da família.

Laqueur nos fornece um panorama riquíssimo dessas transformações; cheio de detalhes. Ele utiliza duas fontes de dados muito interessantes. A primeira consiste em relatos da época sobre episódios de mudança de sexo. Obviamente não estou me referindo a operações cirúrgicas para mudança de sexo; falo de relatos sobre ocorrências espontâneas de mudança de sexo. Por exemplo, relatos de mulheres em quem, por causa de atividade física, os órgãos genitais "desciam” e, assim, se tornavam homens. Por exemplo, o relato sobre a pastora que estava correndo atrás das ovelhas e pulou a cerca, e isso gerou o calor necessário para expulsar o pênis para fora.

A segunda fonte são os textos de anatomistas que mostram discursivamente o esforço de integração de explicações alternativas ao modelo de sexo único. Há textos em que predomina a explicação presa ao modelo de sexo único; outros, numa fase intermediária, em que as explicações mesclam - antecipando aqui alguns conceitos relacionados ao estudo de práticas discursivas, repertórios linguísticos do modelo de sexo único e repertórios do modelo do dismorfismo sexual, até que estes passam a prevalecer.

É esse cuidado de Laqueur com a linguagem que me leva a afirmar que se trata de uma pesquisa arqueológica. Ou até mais; embora Laqueur seja um historiador esse foco no uso da linguagem me leva a pensar que se trata de alguém que estava tentando entender a ressignificação dos repertórios num período de transição histórica. Usei Laqueur para ilustrar a pesquisa de cunho construcionista pelas razões acima (embora não tenha conhecimento da atitude de Laqueur face ao construcionismo). Mas escolhi um historiador de modo a pontuar a importância da história para a pesquisa construcionista. Não é apenas uma questão de compatibilidade; é também uma necessidade, pois para entender os usos atuais é preciso conhecer como foi a evolução dos repertórios linguísticos usados para falar dos fenômenos que estudamos. Os historiadores da estirpe de Laqueur nos dão insumos para isso. Daí a proximidade com a história que passa a ser quase que uma necessidade para quem trabalha com sentidos a partir do estudo da linguagem.

A segunda ilustração de pesquisas de cunho construcionista pula alguns séculos e se refere a acontecimentos dos anos 70 do século XX. Trata-se de texto de Hacking sobre abuso infantil publicado no livro Social Construction of What? Fiquei fascinada porque tenho um doutorando, Ricardo Pimentel Mello, que está pesquisando esse tema e não estávamos localizando nenhuma bibliografia compatível com a perspectiva construcionista e esse texto trouxe, portanto, contribuições importantes.

Hacking parte do princípio que abuso infantil não é uma categoria natural. Ele usa uma terminologia complicada, que em inglês é kind, que vou traduzir como "tipo". Ele diz que esta é uma categoria de tipo interativo, ou seja, abuso infantil existe na interação entre pessoas e seus comportamentos. Você não encontra abuso infantil solto na natureza; ele é produto de comportamentos de pessoas.

Neste texto Hacking enfrenta problemas terminológicos e conceituais complexos entre eles: a noção de ideia, objeto e realidade. Mas, basicamente, o que ele propõe é que a ideia de abuso infantil é datada: emerge numa data específica (1961), num local (Denver), em um grupo muito específico de autoridades (pediatras). Tendo como referência imediata os bebês maltratados, a ideia logo expandiu-se para abarcar outras idades e circunstâncias. Primeiro foi estendido a outros eventos: não mais bebês, mas crianças de várias idades. Em um segundo momento foi legislado e, num terceiro momento, passou a ser incorporado nas práticas profissionais de médicos, educadores, pais e polícia. Para explicar isso, ele retoma a noção de matriz, propondo que essa ideia é formatada em uma matriz que envolve elementos diversos.

Hacking busca entender como a ideia de abuso infantil torna-se um problema social. Por que isto é importante? Afinal a prática, abuso infantil, 
sempre existiu, certo? Em sociedades diversas, em épocas diversas as crianças foram maltratadas e essa prática às vezes era até mesmo culturalmente aceita. Os espartanos jogavam as crianças deformadas penhasco abaixo e algumas tribos indígenas brasileiras matam gêmeos porque consideram que são uma versão do mal. Entretanto, o maltrato na sociedade ocidental só vai adquirir visibilidade na era vitoriana. Foi necessário que surgisse a categoria infância para que o maltrato na infância pudesse fazer sentido. Daí a emergência tão tardia do abuso infantil como problema social.

A preocupação vitoriana com crueldade (que não era só inglesa, tendo desdobramentos na Europa e nos EUA) começa com os escravos: libertação dos escravos e proibição do tráfico dos escravos. Continua com o trabalho fabril, com a crueldade aos animais e só então é pensada a crueldade às crianças. Aliás, é interessante notar que a sociedade britânica anticrueldade aos animais, antecedeu a sociedade anticrueldade às crianças. É uma longa série de preocupações com crueldade que está inserida num espírito de reforma social que, no final do século XIX, gerará uma série de legislações protegendo o trabalho, as crianças, e as mulheres entre outros.

O foco da categoria crueldade é o maltrato físico; não estava ainda em pauta a questão das perversões sexuais ou do abuso sexual. O crime era o maltrato físico. O abuso sexual era tratado em outra esfera, não na esfera legal. O tema do maltrato desaparece por volta de 1910 para reaparecer com novas conotações em Denver, em 1961, num contexto onde a saúde infantil e as tradições familiares passam a ser aspectos importantes do questionamento da destradicionalização da sociedade norte-americana.

Nesse momento, o maltrato já vem ressignificado como abuso infantil, mas com novas conotações. Primeiro, perde qualquer referência a problema social vinculado à classe social ou pobreza (aspectos centrais na reflexão vitoriana sobre infância). $\mathrm{O}$ foco das ações na era vitoriana era as classes mais pobres que tinham que ser sanitizadas, higienizadas e civilizadas. Esse era essencialmente um movimento civilizatório. Em 1961 perde a conotação de classe; perde qualquer conotação de reforma social. Muito pelo contrário, vem inserido no movimento de preservação da tradição. Em segundo lugar, emerge como um problema médico. Finalmente, em terceiro lugar, emerge já no contexto da linguagem dos riscos, acoplado à noção de família em risco e criança em risco. A noção de risco, ausente na questão da crueldade, está totalmente presente nos primeiros discursos públicos sobre abuso infantil.

Esses três aspectos dão ao movimento uma ampliação imediata que afeta os próprios pediatras de Denver. Eles focalizaram inicialmente os bebês maltratados, tendo consciência de que o abuso infantil estendia-se a outras faixas etárias, mas acharam que falando de bebês seria mais fácil angariar apoio. Seria mais fácil também ter apoio público falando de abuso infantil, sem referir-se a abuso sexual. Mas o movimento logo expande-se de modo a abarcar também o abuso sexual. Emerge também como movimento de defesa da instituição família e da moral familiar. Por exemplo, a noção de abuso só foi expandida para abarcar a prostituição infantil mais tardiamente, muito embora existissem estudos mostrando que havia abuso sexual e abuso físico nesse cenário e que a própria situação de prostituição infantil era, por definição, abusiva. O movimento envolveu, sobretudo, a família nuclear e a família extensa no seu sentido moderno: escola e cuidadores entre outros.

Em 1961, esse grupo de pediatras começa a mobilizar-se. Em 1962, eles escrevem um artigo que é publicado no jornal da Associação Médica Americana que publica também um editorial sobre o tema. Quem trabalhou com mídia ou com bancos de dados de publicações científicas, sabe qual é o peso da publicação na revista oficial da Associação Médica Americana e ainda com um editorial dando apoio. Em 1965, a categoria abuso sexual infantil passou a ser incluída no índex médico, que depois de informatizado passou a ser conhecido como Medline. Em 1974, foi aprovada legislação sobre abuso sexual infantil nos Estados Unidos. Em 1976, foi criada uma revista internacional e uma associação internacional específica para o tema. Em 1980, o movimento já tinha chegado ao Brasil, sendo que Brasil e Austrália foram os países que primeiro incorporaram esse discurso. Entretanto, é interessante observar que esse discurso não foi incorporado por todos os países. Hacking menciona uma conferência internacional em que um médico da índia afirma que o abuso infantil mata poucas crianças na índia, sendo que o abuso nutricional mata muito mais. Essa ampliação para incluir os fatores sociais, porém, não foi aprovada.

Qual é a evidência que o abuso sexual infantil é uma prática em crescimento? Não há dados de prevalência (número de casos registrados) e muito menos de incidência (casos novos) de abuso. Como se não bastasse 
isso, a própria definição de abuso vem mudando e ampliando-se, o que dificulta o cálculo. E há ainda a questão da notificação. Hacking apresenta dados indicativos de um crescimento surpreendente no número de casos de abuso infantil. Mas fica a dúvida: trata-se de aumento do número de casos, de melhoria das formas de registro ou de mudança na forma de perceber e descrever o fenômeno?

Hacking apresenta, como exemplo, os dados de um estudo realizado por D. E. H. Russell em São Francisco que buscava mostrar que o abuso sexual intrafamiliar era muito mais frequente do que pensávamos. Para isso ela usou apenas entrevistadoras mulheres e treinou-as de modo a estarem particularmente sensibilizadas para esse problema. Essas entrevistadoras estavam aptas a ajudar as pessoas a interpretar eventos passados à luz do abuso. Russell concluiu que uma em cada duas mulheres em San Francisco haviam sofrido abuso sexual.

Por isso mesmo os números são problemáticos. Esse poder de convencimento que tem o número é uma questão apaixonante. Raramente paramos para perguntar como chegou-se a um dado quantitativo. Esquecemos que, além das dificuldades de definição das categorias que transformam a qualidade em quantidade, há também o problema da forma como o dado foi coletado. O número, portanto, na maioria dos casos merece ser questionado.

Voltando ao caso do abuso sexual infantil, quais são as consequências disso tudo? Há concordância que a revelação do abuso pode ter um efeito liberador para quem foi abusado, pois há, muitas vezes, interdito de revelação: "você não conta que seu pai lhe estuprou, você não conta que sua mãe lhe bateu", às vezes por causa de ameaças reais, às vezes por outras razões. Outro efeito foi o de legitimação da revelação que, para muitas pessoas que sofreram abuso, foi extremamente liberador.

Mas, em contrapartida, o abuso (real ou imaginado) foi usado também, em casos de divórcio, como argumento para pleitear a tutela das crianças. Há também a complicada questão dos limites: o que conta como abuso? Na medida em que o abuso se torna um problema social (ou socialpolítico), a ponto de levar à elaboração de legislação específica, punição, registro em polícia, retirada da criança da guarda dos pais e daí por diante, nos deparamos com a questão dos limites. Quem não lembra do caso do garoto norte-americano que beijou a menina na escola e por isso foi expulso da escola?

Outra consequência que é particularmente interessante para um construcionista, é o efeito de reinterpretação do passado que têm essas novas categorias. O passado está sempre sujeito à reinterpretação e damos sentido aos acontecimentos passados com as categorias que dispomos hoje. Isso está ocorrendo também em relação ao abuso sexual infantil. Por exemplo, teria Lewis Carroll, autor do livro Alice no País das Maravilhas, sido um pedófilo? Muita verve é gasta hoje em argumentar a favor ou contra essa hipótese.

O problema de interpretar fatos passados é que tendemos a presumir que a categoria que hoje parece ser clara e cristalina, também o era no passado. Quem trabalha com homossexualidade sabe disso perfeitamente. É difícil afirmar que um personagem do passado era homossexual. Podia ter práticas sexuais homoeróticas, mas não caberia defini-lo como homossexual tendo em vista que tal categoria só passou a existir no final do século XIX.

A questão da reinterpretação do passado é também complicada do ponto de vista das vítimas de abuso. A rememoração de eventos de abuso (de vários tipos, incluindo o abuso sexual) em situação terapêutica vem sendo questionada em vários fóruns. É muito fácil convencer alguém a reinterpretar a sua infância a partir de uma outra ótica. E se a categoria abuso for ampliada, é muito provável que eventos passados passem a ser reinterpretados como abuso. Tendo em vista que a elaboração dessas memórias pode ter um efeito liberador para quem viveu um caso de abuso e o reprimiu por vários motivos, é delicado lidar com a questão da memória: esta é sempre uma reinterpretação do passado à luz do nosso olhar de hoje. Não há como voltar atrás e reviver a situação por meio de algum tipo de manipulação de áreas de memória do cérebro (e mesmo assim, é possível que tais memórias também sofram a influência do presente).

Essa pesquisa de Hacking ilustra, talvez com mais propriedade do que a de Laqueur, o que é uma pesquisa construcionista. Hacking parte da pergunta: seria o abuso sexual infantil uma categoria inevitável? Não se trata de perguntar se o abuso sexual infantil, como prática social, é inevitável, mas de entender como essa categoria foi construída e os efeitos de governamentalidade a ela associados. 


\section{CAPÍTULO II}

\section{A PROduÇÃo DE SENTIDOS NA PERSPECTIVA DA LINGUAGEM EM AÇÃo}

Uso o termo Práticas Discursivas de modo a reiterar que o foco de interesse da abordagem teórica e metodológica que vem sendo desenvolvida no Núcleo de Pesquisa em Psicologia Social e Saúde, da PUC de São Paulo (doravante referido como "Núcleo"), é a linguagem em uso. Por que a minha preocupação de reiterar isto? Pontuar que é esse o foco é importante porque a linguagem é trabalhada de formas distintas em diferentes disciplinas e, como psicólogos sociais, o interesse maior é no papel da linguagem na interação social. Daí o termo Práticas Discursivas.

A linguagem em uso é tomada como prática social e isso implica trabalhar a interface entre os aspectos performáticos da linguagem (quando, em que condições, com que intenção, de que modo) e as condições de produção (entendidas aqui tanto como contexto social e interacional, quanto no sentido foucaultiano de construções históricas). Talvez a marca distintiva da abordagem que estamos desenvolvendo no Núcleo seja essa ênfase na noção de contexto.

No primeiro módulo deste curso definimos o conceito de matriz proposto por Hacking. Também a linguagem precisa ser entendida em sua matriz de construção de sentidos. Como veremos a seguir, temos trabalhado a noção de repertórios linguísticos a partir de uma matriz que engloba três tempos: o Tempo Longo, o Tempo Vivido e o Tempo Curto. Essa proposta torna a pesquisa com práticas discursivas mais complexas por ser ela, concomitantemente, uma microanálise (o Tempo Curto da interação), uma pesquisa das estruturas sociais geradoras de habitas (o Tempo Vivido) e uma exploração da história das ideias (o Tempo Longo).

Dada esta complexidade, as pesquisas ficam mais ricas quando trabalhamos em grupo e, sobretudo, se trabalhamos numa perspectiva transdisciplinar. No nosso caso, temos feito uma interlocução interessante com pesquisadores da área de história e isso tem ajudado muito. Evidentemente, o tempo longo da história dos repertórios linguísticos tende a apoiar-se em pesquisas já existentes identificadas a partir de revisão bibliográfica. Não sendo historiadores, seria extremamente complicado ter que fazer uma pesquisa histórica para depois entender a linguagem em uso.
É importante pontuar que embora a análise das práticas discursivas dê-se, em última instância, num nível micro, a noção de contexto é abordada em vários níveis. Por exemplo, o contexto da produção da fala constitui um dos focos da análise. Partindo do pressuposto que as pessoas podem expressar-se de maneiras diversas (dependendo de onde estão, com quem estão falando, o que foi dito e qual a forma da interação) buscamos entender por que as pessoas falam certas coisas num determinado momento.

Adotamos o termo Práticas Discursivas em preferência a discurso. Preservamos o termo discurso para falar do uso institucionalizado da linguagem e de sistemas de sinais do tipo linguístico (Davies e Harré, 1990). Essa proposta é interessante, porque permite fazer a distinção entre práticas discursivas - as maneiras pelas quais as pessoas, por meio da linguagem, produzem sentidos e posicionam-se em relações sociais cotidianas - e o uso institucionalizado da linguagem - quando falamos a partir de formas de falar próprias a certos domínios de saber, a Psicologia, por exemplo.

Isso permite também fazer uma distinção entre a análise de material interativo e a análise de documentos de domínio público. É evidente que quando escrevemos um artigo, uma matéria de jornal, um ofício, uma lei, fazemos isso a partir de regras muito claras. Para publicar numa revista científica, por exemplo, temos que atentar para as normas que definem os conteúdos considerados desejáveis e as formas de expressão.

Embora tenhamos procurado fazer tais distinções (entre práticas discursivas e discurso, entre comunicação face a face e documentos de domínio público), temos consciência de que se tratam de distinções didáticas; distinções feitas pragmaticamente. Nesse momento, é assim que estamos conseguindo lidar com a diferença que percebemos em nosso material textual. Mas reconhecemos que as coisas podem mudar à medida que o próprio referencial amadurece; daqui a cinco anos, podemos dizer: não, não existe discurso, só existem práticas discursivas.

O trabalho com linguagem em ação focaliza as maneiras pelas quais as pessoas produzem sentidos e posicionam-se em relações sociais cotidianas. As práticas discursivas têm como elementos constitutivos: a dinâmica (que são os enunciados, orientados por vozes), as formas ou speech genres (que, para Bakhtin, são formas mais ou menos fixas de enunciados) e os conteúdos, os repertórios linguísticos. 


\section{O foco nos Repertórios Linguísticos}

A noção de Repertórios Linguísticos permite diferenciar conteúdos e processos. Trata-se de uma dicotomia complicada, pois, embora reconhecendo que diferenciar conteúdo e processo possa ser uma estratégia didática, a distinção é problemática. Mas por ora penso que, para fins didáticos, vale a pena pontuar que as práticas discursivas se caracterizam tanto pela dinâmica como pelos conteúdos que, no caso, estamos denominando de repertórios linguísticos.

Repertórios Linguísticos são entidades teóricas muito mais fluídas, muito mais flexíveis, que Representações Sociais. As representações são trabalhadas como teorias, como formas compartilhadas de associar repertórios. Consequentemente, quem trabalha com Representações Sociais, por definição, trabalha num nível mais estrutural do que quem trabalha com Práticas Discursivas (ou com uma Psicologia Discursiva). Ao trabalhar com Práticas Discursivas não estamos procurando estruturas ou formas usuais de associar conteúdos. Partimos do pressuposto que esses conteúdos associam-se de uma forma em determinados contextos, e de outras formas em outros contextos. Os sentidos são fluídos e contextuais. Os repertórios são colocados em movimento nos processos de interanimação dialógica que, nas teorizações de Bakhtin (1994), integram as unidades básicas da linguagem e as da comunicação.

Para Bakhtin, as Unidades Básicas de Linguagem são a sentença e a palavra. A sentença é um pensamento relativamente completo: pode ser curta, pode ser um parágrafo, mas é um pensamento relativamente completo que se relaciona a outros pensamentos de um único locutor, em um mesmo enunciado. Aqui já percebe-se que a noção de enunciado de Bakhtin (que veremos a seguir ao abordarmos as unidades básicas da comunicação) extrapola a noção de sentença. A noção de enunciado, ao contrário da sentença e da palavra, é pautada pelo interlocutor e não pela gramática ou pela sintaxe.

A palavra tem pelo menos três dimensões: a Palavra Neutra da Linguagem, ou seja, a palavra dicionarizada; a Palavra do Outro que é cheia dos ecos dos enunciados dos outros (como os outros a utilizam) e $a$ Minha Palavra, usada num plano de fala específico (ou seja, como eu a utilizo). É esse jogo entre as três dimensões da palavra que Bakhtin vai chamar de Interanimação Dialógica.

A Unidade Básica da Comunicação na teorização de Bakhtin é o enunciado. $\mathrm{O}$ enunciado vai da pergunta de alguém até a finalização da fala de outra pessoa. É um elo na cadeia de comunicação. Dai a importância de não descontextualizar trechos das trocas discursivas em nossas análises, pois, ao tirarmos uma sentença do enunciado que lhe dá suporte, lhe roubamos o sentido. A sentença só adquire um sentido completo no contexto do enunciado. Portanto, para entender o processo de interanimação dialógica, é preciso incorporar na análise os vários elos dessa cadeia de comunicação: levar em consideração não só o que a pessoa falou, mas também o que precedeu essa fala - a pergunta do entrevistador, por exemplo. Essas trocas também constituem o contexto de produção de sentidos. Só entendemos o sentido na medida que incorporamos na análise esse contexto mais amplo de perguntas, respostas e intervenções.

Sendo um elo na cadeia de comunicação, o enunciado tem como características as fronteiras, o endereçamento e os speech genres.

Quanto às fronteiras, cada enunciado concreto é definido pela mudança de locutor, aquilo que Bakhtin denomina de change of speaking subject. Pode, portanto, ser demarcado por uma frase ("Bom dia, tudo bem?" "Tudo bem"), por uma sentença ou por várias sentenças. É o conceito de finalização que permite entender a dinâmica das fronteiras de um enunciado. Bakhtin fala de finalização para se referir "ao lado interno" da mudança de locutor. A mudança só pode ocorrer, porque o locutor disse tudo o que queria dizer naquele momento particular, consequentemente, o principal critério da finalização é a possibilidade de resposta ou de assumir uma postura responsiva. Ou seja, o conteúdo discursivo tem que ter o potencial de evocar uma reação de resposta.

Quando elaboramos os mapas, como veremos em outro momento deste curso, percebemos a violência que o entrevistador comete ao insistir em suas perguntas, buscando eliciar mais conteúdos, quando a pessoa, no processo de interanimação dialógica, finalizou o enunciado. Uma das conversas registradas por Vera Menegon (1998) em sua pesquisa sobre menopausa ilustra o conceito Bakhtiniano de finalização. 


\section{CONTEXTO}

Durante uma festa, um grupo de pessoas, quatro homens e três mulheres conversavam descontraidamente. Então, foi apresentada ao grupo uma outra pessoa, uma senhora de uns 60-70 anos. Alguém do grupo falou sobre minha pesquisa, resultando no seguinte comentário:

- A Vera está pesquisando sobre menopausa.

A senhora:

- Menopausa! Que coisa horrível, é melhor esquecer.

Ficou um silêncio geral, inclusive da parte de Vera. A senhora virou para outra pessoa, começou a conversar sobre outro assunto e a menopausa foi devidamente esquecida.

Fonte: Menegon, 1998.

É um exemplo anedótico, digamos, de finalização: uma finalização verbal e postural. Verbal, pois a senhora disse "Que horror!" e encerrou qualquer possibilidade de continuidade. Se tivesse dito "Nossa, que horror...", teria sido possível Vera perguntar "Que horror, por quê?" Mas não, esse "Que horror!" foi categórico e ainda por cima a senhora virou as costas e passou a conversar com outra pessoa. Então, é um exemplo bem anedótico que ilustra o que chamamos de finalização.

A segunda característica do enunciado é o endereçamento. Todo o enunciado é uma resposta ao enunciado que o precedeu. Está, portanto, atravessado de dialogicidade, é esse encadeamento de endereçamentos que chamamos de Interanimação Dialógica. Essas são competências que raramente questionamos (são taken for granted). É quando nos deparamos com rupturas do habitual que prestamos atenção. Por exemplo, no caso das falas de esquizofrênicos. Embora não tenha experiência direta com práticas discursivas de pessoas diagnosticadas como esquizofrênicas durante um surto, sei que há pessoas pesquisando essa temática. É possível perguntar até que ponto a nossa dificuldade com a fala esquizofrênica é que ela foge do endereçamento esperado. Qual é o enunciado ao qual a pessoa está respondendo? Não temos acesso a essa informação; está fora dos nossos processos de socialização. Seria possível, no entanto, imaginar uma análise da interanimação dialógica nessa situação peculiar que é o discurso do esquizofrênico, apoiando-nos no conceito Bakhtiniano de Vozes.

A noção de Speech Genres (por nós traduzido como Gêneros de Fala) é usada por Bakhtin para referir-se às formas relativamente típicas e estáveis de fala que formam o substrato compartilhado que possibilita a comunicação. É isso que nos permite predizer desde as primeiras palavras como se desenvolverá o enunciado. É uma competência que adquirimos no processo de socialização. Os Gêneros de Fala estão atravessados por expressividade, pois, sendo formas típicas de enunciados (e não formas linguísticas), herdam um certo tipo de expressividade que é própria da cultura específica. Mas os Gêneros de Fala são também atravessados por expressividade porque expressam-se em estilos individuais.

Os Gêneros de Fala são aspectos importantes de nossa competência comunicativa no dia-a-dia. Por exemplo, há um gênero de fala típico de consultório médico; há um gênero de fala próprio à situação de aula e há um gênero de fala para casamentos e enterros. Somos socializados a saber que uma situação é alegre, triste ou pomposa; que há ocasiões em que devemos cumprimentar as pessoas e que há formas específicas de cumprimentar em ocasiões diversas. Imagine chegar num velório e ao invés de dizer "meus pêsames", dizer "nossa, que bom, que maravilha! Parabéns!" Isso iria certamente causar um certo grau de surpresa nos que estivessem presentes no velório.

Os Gêneros de Fala aplicam-se tanto a essas pequenas comunicações do dia-a-dia, como às formas de falar próprias às diferentes práticas profissionais. Os homeopatas fornecem exemplos interessantes de interação médica porque muitas vezes rompem com o gênero de fala da clínica médica: conheço um que pergunta data de nascimento para verificar o signo astrológico do cliente. Imagino que um cliente desprevenido deve ficar completamente perdido se tiver sido socializado num gênero de fala de consultório tradicional.

Como a noção de Gêneros de Fala decorre do trabalho de Bakhtin como crítico literário, ele faz uma distinção interessante entre gêneros primários e secundários. Gêneros primários são aqueles que estão muito automatizados; são habituais, muito espontâneos e atravessam as nossas comunicações do dia-a-dia. Os Gêneros de Fala secundários são mais complexos e incluem os vários gêneros literários: novelas, dramas, comentários e textos científicos.

Como aprendemos essas formas complexas de expressão? Pensem na situação em que vocês têm que apresentar um resumo para a comissão organizadora de um congresso científico. Vocês começariam lendo as 
instruções para apresentação de trabalhos: "o resumo deve ser apresentado em tal formato, com um mínimo de x e um máximo de y palavras e incluir os objetivos, procedimentos, análise e principais resultados". Isso é um gênero de fala que é próprio da comunicação científica. $\mathrm{O}$ mesmo aplica-se a um artigo em revista científica. Também elas especificam, nas normas para envio de textos, o gênero que lhes é próprio. Analisando uma variedade de revistas científicas, percebe-se que estes gêneros variam de acordo com as especificidades de cada domínio de saber. Justamente por não haver um padrão único, é importante, nesses Gêneros de Fala secundários, entender as normas que regem o campo específico.

Unidades de linguagem e unidades de comunicação colocam em movimento os conteúdos: os Repertórios Linguísticos.

Os repertórios linguísticos são os termos, os conceitos, os lugarescomuns e figuras de linguagem que demarcam o rol de possibilidades de construções de sentidos. Esses repertórios circulam na sociedade de formas variadas. Aprendemos repertórios no próprio processo de aprendizagem da linguagem, por meio de livros que lemos, dos filmes que assistimos e daí por diante.

Vamos ao museu e vemos um quadro sobre mães e filhos, digamos um quadro renascentista, uma virgem. Nesse mesmo museu, poderemos ver outras expressões imagéticas de mães e crianças: mulheres e crianças da fase azul de Picasso, mulheres e crianças em situação de pobreza nos quadros de Portinari, etc. Ainda nesse mesmo dia, quem sabe acabamos indo ao cinema ver, por exemplo, um filme de Almodóvar. Lá vamos encontrar outras concepções do que é ser mãe e do que é ser filho. Ou seja, em um mesmo dia, nos deparamos com uma diversidade de repertórios sobre maternidade, que são distintos e talvez sejam expressões de épocas históricas diversas ou situações sociais distintas. Os repertórios, portanto, não são aprendidos formalmente. Convivemos com essa diversidade de conteúdos e usos.

Quando trabalhamos com repertórios, a primeira coisa que salta aos olhos é que eles têm longa história. Embora profissionalmente identificados com a Psicologia Social, nas nossas práticas discursivas cotidianas não lidamos apenas com repertórios que são próprios aos Gêneros de Fala ou à linguagem social da Psicologia. Nós entramos e saímos de vários papéis durante o dia e, muitas vezes, usamos repertórios que têm ressonâncias de tempo longo.

Foi esse tipo de preocupação que nos levou a trabalhar a questão do tempo. Essa é uma proposta bastante antiga no percurso de elaboração do referencial teórico e metodológico do Núcleo, datando, pelo menos de 1993 (Spink, 1993). Focalizando o contexto de circulação de repertórios linguísticos, não estamos falando do tempo cronológico, do tempo linear. Isso pode ser complicado na medida em que as pessoas pensam o tempo justamente nessa perspectiva cronológica: o século passado, esse século, ontem, hoje. É difícil muitas vezes entender que, na verdade, nós estamos falando do presente e não do passado. Na perspectiva temporal adotada, lidamos apenas com um passado presentificado. Temos adotado, para abordar essa questão, um esquema temporal tríplice: tempo longo, tempo vivido e tempo curto.

O Tempo Longo focaliza justamente essa longa história da circulação de repertórios linguísticos na sociedade e o fato de que eles não desaparecem ao deixarem de estar presos às condições de sua produção. Permanecem vivos nas produções culturais da humanidade e passíveis de serem reativados como possibilidade de sentidos. Os usos que fazemos deles podem ser muito diferentes, mas os repertórios têm este tempo longo que inclui desde as primeiras produções linguísticas e pictóricas que temos conhecimento. Falo em produções pictóricas, porque as imagens são também elas produtoras de repertórios. Como usamos a linguagem para significar a imagem, ela é também contexto de produção e circulação de repertórios linguísticos.

Usamos o Tempo Vivido basicamente para falar do tempo de socialização. Aprendemos a usar repertórios a partir das nossas posições de pessoas: a família em que fomos criados; a escola que frequentamos. Esses diferentes contextos de socialização definem as oportunidades de contato com repertórios, Gêneros de Fala e linguagens sociais. Temos encontrado apoio teórico para pensar esse tempo no conceito de habitus proposto por Bourdieu (1994) que o define como o sistema de disposições duráveis, estruturas estruturantes que funcionam como matriz de percepções, apreciações e ações. O Tempo Curto é o tempo das interações; o tempo da interanimação dialógica. É nesse tempo que podemos entender a dinâmica 
da produção de sentidos. O momento da produção de sentido, portanto, é o momento do aqui e agora.

Resumidamente, então, o Tempo Longo é o domínio da construção dos conteúdos culturais que foram parte dos discursos de uma dada época. Permite que nos familiarizemos com os conhecimentos produzidos e reinterpretados por diferentes domínios do saber: religião, ciência, conhecimentos e tradições do senso comum, entre eles. O Tempo Vivido é o tempo de ressignificação destes conteúdos históricos a partir dos processos de socialização. É o tempo de vida de cada um de nós; tempo da memória na qual enraizamos nossas narrativas pessoais e identidades. $\mathrm{O}$ Tempo Curto é o tempo da interanimação dialógica e da dinâmica da produção de sentidos. É nesse tempo que se presentificam as diferentes vozes ativadas pela memória cultural do tempo longo ou pela memória pessoal do tempo vivido.

\section{A linguagem e os processos de interanimação dialógica}

Passarei a focalizar, agora, as práticas discursivas propriamente ditas e procurar definir o que são sentidos, interanimação dialógica e posicionamento na perspectiva teórica da produção discursiva de sentidos.

De uma forma ou outra, todo mundo trabalha com produção de sentidos. Quem trabalha em clínica lida com produção de sentidos; quem trabalha em Psicologia Social também está procurando entender os sentidos. Os sentidos da vida cotidiana são o pão-pão queijo-queijo do psicólogo. Não só do psicólogo, mas do sociólogo também. Sentido não é, portanto, propriedade de um referencial teórico único: é a tarefa básica de todos os cientistas sociais. Só que cada disciplina e subdisciplina trabalha a produção de sentidos de uma forma específica. Digamos, então, que a nossa forma específica, no Núcleo de Psicologia Social e Saúde, na PUCSP, é apenas uma das vertentes possíveis da análise da produção de sentidos.

O sentido é uma construção social, um empreendimento coletivo mais precisamente interativo, por meio do qual as pessoas, na dinâmica das relações sociais, historicamente datadas e culturalmente localizadas, constroem os termos a partir dos quais compreendem e lidam com as situações e fenômenos a sua volta. Esta é a definição que estamos usando para falar a respeito do tipo de pesquisa que realizamos. Embora muito simples a definição, os termos epistemológicos e ontológicos estão todos especificados. Nós estamos frisando que o sentido é uma construção social e, como tal, um empreendimento coletivo. Tomamos a produção de sentidos como um processo interativo: ninguém produz sentido individualmente. Situamos o sentido como uma construção social, e enfatizamos que tal construção se dá num contexto, numa matriz que atravessa questões históricas e culturais e que é essa construção que permite lidar com situações e fenômenos do mundo social.

Produzimos sentidos o tempo todo. Não se trata de atividade que fazemos de repente: entrei no consultório médico, então agora vou produzir sentido. Não é isso. Se não dermos sentido às normas e às regras que regem nosso mundo, estaríamos em maus lençóis. Se não déssemos sentido, por exemplo, ao semáforo e simplesmente atravessássemos a rua, não percebendo o que significa o vermelho, o verde, o amarelo, provavelmente seríamos atropelados, com graves consequências físicas.

Produzir sentido, portanto, é o que permite lidar com situações e fenômenos do dia-a-dia, do cotidiano. Podemos fazer um recorte das atividades do cotidiano e analisar os processos de produção de sentido. Nós, como pesquisadores, é que decidimos: quero entender como é construído o sentido sobre 'x', 'y', 'z'. Então, esse 'x', 'y', 'z' provém de um interesse nosso como pesquisadores, pois o processo de produção de sentido é contínuo e não se limita a essa escolha temática para fins de pesquisa.

Na perspectiva da linguagem em uso, o sentido é sempre interativo: os enunciados de uma pessoa estão sempre em contato ou são endereçados a uma outra pessoa e esses endereçamentos se interanimam mutuamente, mesmo quando os diálogos são internos; ou seja, na perspectiva bakhtiniana não existe o monólogo.

Os processos de produção de sentidos implicam existência de interlocutores variados cujas vozes se fazem presentes. As práticas discursivas estão sempre atravessadas por vozes; são endereçadas e, portanto, supõem interlocutores. Obviamente isso gera dificuldades consideráveis quando analisamos material discursivo, porque as pessoas, numa entrevista, por exemplo, estão falando com você e de repente a fala passa a ser endereçada a outrem. Por exemplo, "não sei... porque meu pai dizia que..." O interlocutor passou a ser o pai. É um trabalho instigante esse de tentar identificar estas mudanças de interlocutores. Numa pequena 
entrevista de cinco minutos podem aparecer vários interlocutores, imaginem então uma entrevista de uma hora!

Quanto à interanimação dialógica, Bakhtin afirma que, distinguindose das unidades de significação da linguagem (as palavras e sentenças) que são impessoais, não pertencem a ninguém e não são endereçadas a ninguém, o enunciado tem tanto um autor (e, portanto, expressividade) quanto um destinatário. Esse destinatário pode ser um participante que é interlocutor imediato e que está presente em um diálogo do cotidiano; um coletivo diferenciado de especialistas em alguma área de comunicação cultural específica; um público mais ou menos diferenciado; um grupo étnico; contemporâneos; pessoas de mentalidade semelhante; oponentes e inimigos; subordinados; um superior; alguém que lhe é inferior; familiares; estrangeiros e daí por diante. E pode ser também um outro indefinido, genérico.

A composição e, em especial, o estilo do enunciado depende de várias coisas: para quem o enunciado é endereçado; como o locutor (ou escritor) percebe e imagina seus destinatários e a força do efeito dessa percepção no enunciado. Cada gênero de fala, em cada arena de comunicação de fala, tem sua concepção típica de destinatário, e é isso que o define como gênero (Bakhtin, 1994).

\section{Posicionamento: a produção discursiva de selves}

Outra noção importante para o estudo da produção de sentidos a partir da linguagem em uso é o posicionamento, uma noção mais dinâmica que identidade. Identidade é uma noção mais estrutural, mais fixa, mesmo quando pensada no enquadre da metamorfose (Ciampa, 1987). Metamorfose ainda é a mudança de 'A' para 'B', presume assim um substrato fixo. Já o posicionamento é absolutamente fluído e contextual. São posições de pessoas assumidas (conscientemente ou não) no processo de interação como produtos da interação. São todas as maneiras em que as pessoas, por meio de suas práticas discursivas, produzem realidades sociais e psicológicas (Davies e Harré, 1990).

Posicionar-se implica navegar pelas múltiplas narrativas com que entramos em contato e que se articulam nas práticas discursivas. $O$ posicionamento, como é por nós utilizado, é o processo discursivo no qual os selves são situados nas conversações como participantes observáveis e subjetivamente coerentes em termos das linhas de história conjuntamente produzidas. Ou seja, o self sempre se situa numa linha de história que é produzida em determinados contextos.

Essas posições de pessoa podem ser ilustradas com as múltiplas versões de curriculum vitae que encaminhamos para empregos variados. Se o encaminhamos para uma empresa, destacaremos certos elementos de nossa linha narrativa histórica e não outros. Se quisermos apresentá-lo para uma universidade, destacaremos outros pontos que serão ainda distintos dependendo da universidade. Se vamos contar nossa história de vida para alguém que estamos tentando seduzir, selecionaremos certos elementos compatíveis com a posição de sedução. Ou seja, todos esses elementos são passíveis de serem apresentados de forma coerente, se bem que variem dependendo do contexto.

Quando analisamos práticas discursivas, tomamos esses posicionamentos como produções conjuntas. Harré (Davies e Harré, 1990) propõe que pode haver posicionamento interativo, onde o que uma pessoa diz posiciona o outro; e pode haver posicionamento reflexivo, no qual nos autoposicionamos. Seria bom, entretanto, considerar que, em qualquer destes casos, o posicionamento é necessariamente intencional. Então, na dinâmica da interação, podemos até nos posicionar conscientemente de alguma forma específica, mas no fluxo da interação o interlocutor pode nos posicionar de forma tal que exija uma reorientação (ou reiteração) da posição inicial. Vivemos nossa vida em termos da produção continuada do self, seja quem for o responsável por esta produção. 


\section{CAPÍTULO III}

\section{AS MÚLTIPLAS FACES DA PESQUISA SOBRE PRODUÇÃO DE SENTIDOS NO COTIDIANO}

Muitos trabalhos de pesquisa qualitativa com material discursivo descolam as falas de seu contexto interativo de produção. O material é lido, são feitas interpretações e, então, recortados trechos ilustrativos dessas interpretações. Com isso, desaparece a interanimação dialógica, o jogo de posicionamentos fica escamoteado e ofusca-se o procedimento de coleta de dados e suas ressonâncias nos conteúdos discursivos.

\section{Os mapas, as árvores de associação e as linhas narrativas}

Os mapas possibilitam preservar o contexto interativo e têm ainda uma série de vantagens adicionais. A primeira delas é prover um excelente instrumento de ensino de entrevista. No inicio do curso de Mestrado eu presumia que tinham adquirido competência em entrevista durante o curso de graduação. Eventualmente comecei a duvidar dessa certeza e passei a perguntar em que disciplina haviam aprendido a entrevistar ou, pelo menos, qual a disciplina que lhes dava um feedback sobre as entrevistas realizadas para fins variados. Descobri, assim que, muito embora a entrevista é o método priorizado pela maioria das pesquisas em Psicologia Social na PUCSP, a competência como entrevistador(a) é presumida (e não ensinada).

Os mapas são instrumentos de visualização do processo de interanimação que possibilitam, entre outras coisas, mostrar o que acontece quando perguntamos certas coisas ou fazemos certos comentários. Possibilitam, sobretudo, nos sensibilizar para a existência de múltiplas modalidades de diálogos. Por exemplo, certas entrevistas são conduzidas como inquéritos: a entrevistadora chega com seu roteiro e procura garantir que deu conta de todas as questões dele constantes. Pode ser até mesmo uma entrevista aberta ou semi-estruturada, mas o efeito de aprisionamento do roteiro aparece no mapa com a forma de inquérito. Não se parece necessariamente com um inquérito policial, porque os objetivos são outros, mas o efeito na corrente comunicativa é parecido. A pessoa fica com pouco espaço para se expressar para além do roteiro.
Fomos percebendo também que o que chamamos de diálogo é uma atividade bastante complexa que envolve uma série de estratégias de fala, que incluem a narrativa, a argumentação, os depoimentos, etc. Dessa constatação emergiram perguntas diversas, por exemplo: que perguntas suscitam uma narrativa? Que perguntas geram processos de negociação de sentido? Quando se torna necessário justificar? Em que tipo de interação passa a ser necessário argumentar contra ou a favor de algo? O mapa permite também entender essa diversidade. Então, ele acabou sendo uma técnica central no trabalho de análise de práticas discursivas que vem sendo desenvolvida no Núcleo.

Creio que o Mapa (inicialmente denominado Mapa de Associação de Ideias) foi por mim desenvolvido em uma pesquisa sobre hipertensão, tendo sido apresentado em um congresso sobre Psicologia da Saúde realizado na Inglaterra em 1992 e publicado pela primeira vez em 1994. Denominei essa técnica de Mapa de Associação de Ideias porque, na época eu trabalhava com a teoria das Representações Sociais e isso me possibilitava entender como os conteúdos se organizavam em torno de núcleos temáticos. Mudou a teoria, a técnica modificou-se para adaptar-se aos novos interesses, mas a nomeação permaneceu. Atualmente temos simplificado essa nomenclatura e denominado esse procedimento de análise simplesmente de Mapas. Tratase, entretanto, de nomenclatura em evolução; os Mapas, afinal, remetem a um estilo de exploração de territórios que tem como pressuposto a existência objetiva de terrenos cujas características podem ser reproduzidas em imagens!

O Mapa é uma tabela onde as colunas são definidas tematicamente. Os temas, em geral, acabam refletindo o roteiro de entrevista, porque ninguém vai para o campo de pesquisa dizendo: "fala!". Todo mundo diz: "fale sobre", "me conte sobre" ou "o que você pensa disso". Então, obviamente, a entrevista acaba reproduzindo um roteiro que pode ser menos explícito ou mais explícito; mas existe, porque a pesquisa assim o exige. Em parte, a definição das colunas que sistematizam a entrevista (ou o material discursivo) está relacionada a esse processo de organização de conteúdos de uma interação discursiva muito peculiar gerada pelo procedimento de pesquisa. Mas essas colunas temáticas nem sempre podem ser definidas a priori. Embora os roteiros imponham uma forma à interação, nem sempre os interlocutores respeitam essa forma. Os Mapas têm essa característica interessante de mostrar como as pessoas são resistentes aos 
roteiros. Muitas vezes, as pessoas burlam reiteradamente o roteiro e falam de temas que são para eles mais importantes e que você tem que levar em consideração (senão na entrevista, pelo menos na análise!). Por essas razões, os Mapas não têm temáticas predefinidas. A definição das temáticas organizadoras dos conteúdos da entrevista já é o processo de interpretação. Se as temáticas não fazem violência ao conteúdo da entrevista, a interpretação flui e isso fica óbvio pela facilidade de cortar a entrevista transcrita e colar nas colunas do mapa. Quando há dificuldade, quando as falas não se encaixam nas colunas, é porque as categorias temáticas não estão funcionando. Assim os Mapas têm ainda essa vantagem de orientar o processo de análise.

Quando as entrevistas são muito grandes, muito complexas, ou especialmente quando se está trabalhando com grupos, temos adotado a prática de iniciar o processo de análise com a transcrição sequencial. Essa é uma forma de reduzir a complexidade. A transcrição sequencial é feita escutando a fita, portanto, antes da transcrição propriamente dita. Trata-se de um resumo da entrevista (ou discussão de grupo) onde é feita uma síntese da fala de cada interlocutor, buscando não extrapolar o limite de uma linha por tema/interlocutor. Isso permite entender a dinâmica das trocas discursivas (quem fala, quando fala, sobre o quê) e, sobretudo, ter uma visão de conjunto das temáticas em discussão. Isso possibilita, ainda, optar por analisar apenas os temas que são prioritários para os objetivos de pesquisa. Quando a entrevista é muito comprida ou quando é complexa porque se trata de um grupo, a transcrição sequencial permite dar ao leitor ou leitora uma visão do todo e justificar porque elegeu algumas temáticas (ou trechos da entrevista/grupo) para uma análise mais detalhada. Tanto faz o tipo de material textual, o aspecto que merece destaque é que dessa forma nunca perdemos o contexto da fala, mesmo que trabalhemos apenas com parte do material. É importante, na pesquisa com práticas discursivas, poder se referir ao todo.

Poder explicitar os passos da análise e justificar as opções analíticas é o que define o rigor em pesquisa qualitativa. Para visualizar esse procedimento, podemos pensar nas bonecas russas (um jogo de encaixe de bonecas de diferentes tamanhos). Você pode optar por focalizar apenas uma dessas bonecas, mas é importante saber que essa boneca escolhida encaixase numa maior que por sua vez encaixa-se noutra boneca maior, e daí por diante. Isso possibilita que o interlocutor entenda a parte em relação ao contexto maior.

Além dos Mapas, usamos Árvores e Linhas Narrativas. Essas várias técnicas têm seus objetivos e momentos no processo de análise. Começamos, em geral, com a transcrição sequencial. Tendo decidido que temas serão incluídos nos Mapas, o próximo passo é a transposição dos trechos da entrevista (preservando toda a sequência da interação entre entrevistador e participantes) para o Mapa. O terceiro passo é a construção das Árvores de Associação que visam dar visibilidade ao encadeamento de repertórios nos trechos que nos parecerem ser mais ilustrativos dos fenômenos em estudo. Já a Linha Narrativa é usada, se e quando houver passagens na entrevista que utilizam essa forma discursiva. A Linha Narrativa dá visibilidade à ordenação temporal dos eventos relatados.

Para ilustrar o uso dessas técnicas de análise vou apresentar três pesquisas. A primeira é um estudo sobre Hipertensão Arterial Essencial, parte do qual está publicado no livro Textos em Representação Social (Spink, 1994b). Nessa fase, eu ainda estava trabalhando com a teoria das Representações Sociais, mas já estava em um período de transição e, portanto, mais interessada na linguagem em uso. Buscava, nessa pesquisa, entender as diferentes formas de falar sobre a hipertensão arterial essencial levando em consideração as diferentes posições de pessoas: médicos, clientes de serviços de saúde público e particular, homens e mulheres. Contei com a colaboração de um médico clínico geral que trabalhava em uma clínica particular e em um serviço público de saúde. São consultas muito cuidadosas e todo mundo que ouve a fita diz: "uau, que médico fantástico!". Certamente ele escolheu com cuidado as consultas a serem gravadas! Depois entrevistei esse médico e os quatros pacientes. Assim, contava com quatro situações de clínica médica, uma entrevista individual com o médico e quatro entrevistas individuais com os pacientes.

$\mathrm{O}$ exemplo de Mapa aqui apresentado refere-se a um pequeno trecho do início da entrevista onde formulo a pergunta inicial: "o que é hipertensão para você?" Toda a entrevista, embora longa, foi transferida para o Mapa, pois essa era a proposta metodológica nessa época. As cinco colunas do mapa refletem as temáticas relacionadas com o objetivo da pesquisa: (1) o que é hipertensão, (2) que é o hipertenso, (3) como a Medicina trata a hipertensão, (4) como os pacientes lidam com a hipertensão e (5) o afeto 
presente nas falas. No caso da coluna (3), sobre como a Medicina lida com a hipertensão, a coluna foi subdividida em função do estilo próprio desse médico que pontuava a diferença entre a forma como a Medicina em geral lida com a hipertensão e a sua forma de conduta: "a medicina faz assim, mas eu faço desta maneira". Também a coluna (5), relativa à maneira como o médico via os pacientes lidarem com a hipertensão, merece explicação. Nessa fase (em 1992), embora teorizasse que não é possível separar conteúdos cognitivos e afetivos, ainda sentia a necessidade de dar um destaque especial aos conteúdos afetivos. Nessa análise, o entrevistador não se fez presente; essa dialogia, na medida que o referencial evoluiu para o foco na interanimação dialógica, passou a ser plenamente incorporada aos Mapas. Mas prefiro mostrá-los tal como foram desenvolvidos na época em que foram feitos, pois acho interessante mostrar como o método evoluiu.

Seguindo a cronologia do desenvolvimento dos Mapas como técnica para análise de práticas discursivas, o segundo exemplo refere-se à pesquisa conduzida com Glória Gimenes (Spink e Gimenes, 1994) sobre os sentidos do câncer da mama para mulheres que tinham tido o câncer e mulheres que não tinham tido tal experiência. Essa pesquisa foi de fundamental importância para aperfeiçoamento das metodologias para estudo do sentido na perspectiva das práticas discursivas (Spink, 1997a), incluindo aí a "entrevista associativa".

Pretendíamos inicialmente usar histórias de vida para coleta de dados, pois queríamos entender a adoção de estratégias preventivas ao câncer da mama à luz das representações de corpo e de saúde e doença. As primeiras experiências feitas com essa metodologia resultaram em entrevistas longas e difíceis de analisar pelo excesso de conteúdos. Considerando que pretendíamos comparar dois grupos de mulheres e que prevíamos a realização de cerca de 40 entrevistas, buscamos opções alternativas para a coleta de dados. Acabamos desenvolvendo a técnica de Entrevistas Associativas que eram divididas em blocos temáticos (corpo, seio, saúde, doença, câncer). Cada bloco abordava três dimensões: (1) associativa ("o que vem à sua cabeça quando falamos a palavra corpo"); (2) avaliativa/ expressiva ("como é o corpo para você") e (3) evolutiva/ mnemônica ("e foi sempre assim?"). Como Glória Gimenes trabalhava com coping, sendo objetivo da pesquisa entender também como as mulheres que tiveram câncer da mama haviam lidado com essa doença, a entrevista concluía solicitando às entrevistadas que falassem da doença mais marcante em suas vidas e como haviam lidado com ela. São lindíssimas essas entrevistas: curtas, mas ricas em conteúdos o que vem desmistificar a concepção de que é preciso ter entrevistas longas para trabalhar com sentidos.

Os Mapas refletiram a estrutura da entrevista associativa contendo, portanto, quatro colunas/dimensões: (1) objeto (porque cada bloco tinha um objeto associativo específico: corpo, seio, etc.); (2) primeiras associações; (3) outras associações/ explicações e (4) qualificadores, ainda um resquício da cisão desnecessária entre aspectos cognitivos e afetivos. Essa forma de análise propiciou também o desenvolvimento das Árvores Associativas que possibilitam entender como cada microargumento é construído, preservando ainda - pela presença da fala dos entrevistados - o foco na coconstrução desses argumentos (ver Spink e Lima, 1999 para uma descrição mais detalhada).

Nessa fase, ainda achávamos que toda a entrevista tinha que ser transportada para os Mapas e, obviamente, estes funcionaram bem para a parte associativa da entrevista, mas não para a segunda parte: ao falar da experiência da doença mais marcante, a forma dialógica resultante da associação de ideias dava lugar a longas narrativas para as quais as dimensões definidas para o Mapa Associativo não eram adequadas. Passamos, então, a trabalhar as narrativas com outra técnica: as Linhas Narrativas, sobre as quais falarei mais tarde.

Finalmente, o terceiro exemplo ilustrativo do trabalho com Mapas provém da pesquisa de Odette Godoy de Pinheiro (Pinheiro, 1998) sobre as queixas trazidas por usuários de um serviço público de saúde mental. O objetivo desse estudo era entender como as pessoas aprendem a falar a linguagem social do serviço de saúde de modo a serem encaminhadas para onde elas querem. Se chegarmos ao serviço e dissermos que estamos com taquicardia, provavelmente seremos encaminhados para a clínica médica ou para a cardiologia. Agora, se dissermos que andamos muito nervosos e estamos com taquicardia, aumenta a probabilidade de sermos encaminhados para o serviço de saúde mental. Obviamente, estou me referindo ao acolhimento na unidade de saúde: estou falando da recepção e não do atendimento médico. Nossa hipótese era que o sucesso no encaminhamento dependia da aprendizagem da linguagem social do serviço. 
Assim, Odette observou o serviço de recepção e acompanhou as pessoas que eram encaminhadas para o serviço de saúde mental. Participou durante um tempo dos grupos de acolhimento nesse serviço e, depois das reuniões, fazia o convite para a entrevista que seria conduzida na residência do (a) próprio (a) entrevistado (a). Pouquíssimas pessoas se dispuseram a participar; todos tinham desculpas variadas, algumas das quais bastante curiosas. Odette analisou duas das entrevistas realizadas que foram escolhidas por causa do contraste que ofereciam. Ambas as entrevistadas eram mulheres.

Já nesta etapa de desenvolvimento do referencial teórico e metodológico do estudo das práticas discursivas a entrevista não era mais transferida para Mapas em sua totalidade. Utilizávamos a transcrição sequencial para a definição das temáticas e apenas essas eram analisadas em Mapas. Entretanto, inseríamos o número de linhas na entrevista como um todo de modo a não perder a visão do todo. Os trechos analisados em Mapas podiam ser facilmente localizados na transcrição integral da entrevista: a solução encontrada para não perder de vista o contexto de produção que sustenta os sentidos presentes no trecho analisado.

Como o foco dessa pesquisa era o sentido de sofrimento mental, dois Mapas abordaram essa temática buscando comparar as falas das duas entrevistadas. O primeiro buscava entender os sentidos do sofrimento mental e para isso foram definidas as seguintes dimensões: (1) como é nomeado o sintoma como é descrito, (3) como é explicado, (4) como é referido pelos outros. O segundo, buscava entender a busca de ajuda profissional, sendo definidas quatro dimensões dessa busca: (1) como chega ao serviço (ou profissional), (2) quem atende, que soluções são propostas e (4) como avalia o atendimento.

Entretanto, a transcrição sequencial deixou evidente que a problemática presente em cada uma das duas entrevistas era muito distinta: em uma das entrevistas estava mais voltada à questão da sexualidade lésbica e na outra à explicação das "crises de nervos". Consequentemente, além dos Mapas comuns (sobre sofrimento mental), foram elaborados mapas específicos relacionados com os conteúdos nucleares de cada entrevista.

Retomando agora as Linhas Narrativas, aconteceu de eu estar dando um curso sobre práticas discursivas na época em que morreu a princesa
Diana. Fiquei fascinada com as reportagens sobre esse acontecimento e comecei a integrar o material coletado na mídia como exemplo no curso que estava ministrando, incluindo aí a reportagem sobre a morte da Diana publicada na Folha de São Paulo (FSP) em 01/09/1997 (ver Spink e Lima, 1999).

Uma Linha Narrativa tende a ser uma linha de tempo. As pessoas organizam suas histórias dessa maneira, embora nem sempre ela seja apresentada na forma de uma linha de tempo sequencial. Muitas vezes as pessoas começam falando de um evento passado ("Olha, quando eu casei...") para referir-se a uma situação presente ("agora...") Portanto, muitas vezes a transposição para uma linha de tempo sequencial é uma reconstrução. Mas no caso da matéria da Folha de São Paulo sobre a morte da princesa os dados foram de fato apresentados cronologicamente.

Para analisar essa matéria de jornal, utilizamos algumas das estratégias desenvolvidas para o trabalho com Mapas: utilizamos três dimensões: eventos (na parte inferior da linha de tempo), nomeação e conotação afetiva (na parte superior da linha de tempo). As datas constantes da linha de tempo respeitam os eventos destacados na matéria: por exemplo, "em 10 de julho de 1961, nascia Diana, a terceira filha do Visconde Althorp, para o desapontamento dos pais que queriam um filho". A sentença posiciona Diana (nomeação) como a que veio sem ser desejada. Já sabemos, então, que história que vai ser contada: a narrativa da desvalida.

A Linha Narrativa permite entender as estratégias usadas para argumentar, explicar, justificar e dessa forma fazer valer uma certa interpretação dos acontecimentos. A nomeação é muitas vezes um indicador desse processo de argumentar a favor de uma determinada interpretação. Assim, se a pessoa está narrando sua experiência com uma doença, digamos câncer, é interessante entender quando e em que contexto ela o nomeia câncer, doença, mal e daí por diante. Na pesquisa sobre câncer da mama, encontramos narrativas em que a nomeação mudava na medida em que o contexto da ação também se modificava. Por exemplo, a palavra câncer era usada para relatar a parte médica (“Ai, eu fui ao médico, eu fiz mamografia, aí acusou o câncer"); a palavra doença era usada para falar das consequências pessoais ("Aí para mim foi muito difícil, essa é uma doença complicada"). 
Em suma, o trabalho com Linhas Narrativas não visa apenas ordenar cronologicamente os eventos. Visa, sobretudo, dar visibilidade às características da construção discursiva.

\section{Trabalhando com repertórios linguísticos}

Nem sempre o termo que define nossa área de interesse - menopausa, sexualidade, risco - faz parte do vocabulário espontâneo do grupo com o qual estamos trabalhando. Por isso é interessante começar a pesquisa fazendo uma breve observação de campo, uma observação de tipo etnográfico, escutando a fala espontânea das pessoas que participarão de nosso estudo: jovens, jovens de classes sociais diferentes, mulheres, pessoas da roça e daí por diante.

Digo isso porque vou usar como exemplo a pesquisa sobre risco que venho desenvolvendo desde 1996. Risco é uma palavra que entra no léxico das sociedades ocidentais apenas no século XVII: uma palavra nova para falar de uma nova visão de mundo que permite pensar no futuro que é passível de controle. Risco é um termo utilizado para falar sobre o futuro; mais precisamente, sobre um futuro que é passível de controle. Ou seja, é preciso abandonar a visão de mundo onde as coisas são determinadas por Deus de modo a poder incorporar o vocabulário do risco.

Tenho uma aluna (Edna Roland) que é ativista do movimento negro e está atuando junto aos quilombos do estado de São Paulo. Ela resolveu trabalhar com Oficinas sobre Risco, uma técnica que desenvolvemos no Núcleo para pesquisar risco na vida cotidiana. Ela voltou triste porque não pôde realizar a oficina com o roteiro original, tendo sido necessário usar a palavra perigo dado que, nesse quilombo, a palavra risco não era utilizada (sobre o vocabulário de risco numa perspectiva histórica, ver Spink, 2001). Esse episódio serve de alerta para quem vai trabalhar com repertórios linguísticos. Verifique primeiro quais são os repertórios espontâneos do grupo com o qual estão lidando. Caso contrário cria-se um problema a mais: as pessoas têm que incorporar o novo termo aos termos usuais.

A pesquisa histórica com repertórios linguísticos que vem sendo por nós desenvolvida é um esforço coletivo do Núcleo. Esse é, portanto, o momento de apresentar esse coletivo. O Núcleo de Pesquisa em Psicologia Social e Saúde da PUCSP integra orientandos, bolsistas de Iniciação
Científica e membros do Grupo de Pesquisa Imaginário e Práticas Social (CNPq). É nesse fórum que são desenvolvidas as reflexões teóricometodológicas relacionadas com o estudo das práticas discursivas do cotidiano, embora tenhamos também preocupação com a aplicação prática dessas ideias: muitos dos alunos e colaboradores estão envolvidos em trabalhos junto a comunidades variadas ou estão inseridos em serviços de saúde. Procuramos fazer com que essas reflexões não fiquem apenas no nível de teoria.

O Núcleo/Grupo de Pesquisa tem duas linhas principais de pesquisa: Cotidiano, Memória e Práticas Discursivas (centrada na natureza do conhecimento e por isso mesmo tem um teor mais teórico-metodológico) e Sentidos da Saúde e Doença. Embora essas duas linhas de pesquisa deem conta da diversidade de temas de mestrandos e doutorandos, os membros do Núcleo participam de outras pesquisas coordenadas por mim. Assim, o projeto de pesquisa que usarei como exemplo nessa aula é parte do projeto integrado do $\mathrm{CNPq}$ intitulado Risco e Sociedade contemporânea: vivendo na sociedade de risco, do qual participaram vários orientandos.

Esse projeto incluía três subprojetos: (1) o papel da mídia na circulação dos repertórios sobre risco; (2) o risco na Psicologia e (3) o risco na educação em saúde. A pesquisa como um todo visava mapear os sentidos possíveis de risco, situando-os no contexto histórico do imaginário social sobre riscos e perigos; buscava, assim, situar a linguagem de risco (essa é a expressão que venho utilizando) no contexto maior das sensibilidades contemporâneas e dos modernos processos de governo dos riscos. Essa temática insere-se no conjunto de estudos sobre sociedade contemporânea, modernidade tardia, e o papel que a noção de risco teve na formatação de vários instrumentos de governamentalidade dos processos sociais.

Risco é um dos instrumentos de disciplinarização do corpo. É com o conceito de risco, instrumentalizado pela epidemiologia e operacionalizado pela educação em saúde, que se torna possível pensar a prevenção e a educação na área da saúde. Educar, no contexto da saúde, é basicamente sensibilizar para evitar riscos. Também a Psicologia tem aí papel importante: o conceito de risco não deriva da Psicologia, mas é incorporado por ela para falar de uma série de fenômenos da ordem da pessoalidade. É por essa razão que esse projeto integrado de pesquisa tem esses três eixos: o 
conceito de risco em educação e saúde; a incorporação do conceito de risco na Psicologia e as formas de circulação na mídia.

Para estudar os usos da Linguagem dos Riscos na Psicologia, usamos o PsychInfo, banco de dados que agrega textos da área desde o começo, 1887. De modo a dar conta desse largo período de tempo, 1887 a 1998, trabalhamos com uma amostra representativa de artigos com risco no título. Optamos por analisar apenas artigos com risco no título porque isso garantiria a inclusão apenas de artigos focados especificamente na questão do risco.

Algumas das conclusões foram que a produção sobre risco na Psicologia tende a privilegiar três abordagens. A primeira vertente focaliza a percepção dos riscos. A segunda vertente triangula conhecimento, atitude, comportamento de modo a entender os processos de tomada de decisão sobre risco, mais comum nos estudos organizacionais ou voltados à tomada de decisão sobre investimentos na economia. A terceira vertente concerne os estudos de risco na ótica dos estilos de personalidade.

Para estudar Risco em Educação e Saúde usamos o banco de dados Medline utilizando procedimento amostrai semelhante ao estudo sobre risco na Psicologia. O Medline é o banco informatizado do Index Medicus que data do final do século XIX. Entretanto, apenas os dados de 1966 em diante estavam informatizados nesse banco. Trabalhamos, aqui, com a nomeação do risco e sua relação com as teorias de prevenção.

Entretanto, é o terceiro eixo da pesquisa, sobre a Circulação da Linguagem dos Riscos na Mídia (Spink et al, 2002), que selecionei para ilustrar o trabalho com repertórios linguísticos. O objetivo desta (e dos demais braços da pesquisa sobre risco) era entender o uso que é feito da linguagem dos riscos. Definimos linguagem dos riscos como práticas discursivas que buscam falar de experiências e comportamentos relacionados com situações que implicam a possibilidade de ganhos ou perdas. Abarca, portanto, tanto o uso formal do conceito de risco, como o uso informal, de senso comum; concerne tanto à palavra risco como às demais palavras do glossário sobre risco que são utilizadas para falar de ganho e perda numa perspectiva de futuro.

Risco é uma palavra que entra nos léxicos europeus apenas no século XVII. Entretanto, antes disso havia uma diversidade de palavras para se referir a eventos da vida que implicavam possibilidades de perdas, por exemplo, perigo. Para entender essa polissemia, foi feita uma primeira exploração sobre a linguagem dos riscos na Folha de São Paulo. Elegemos trabalhar com a Folha de São Paulo porque esse jornal conta com um acervo disponível para o público e isso, por incrível que pareça, é uma grande dificuldade nos estudos de mídia no Brasil. A Folha tem um acervo completo disponível perante pagamento; os exemplares de 1994 a 1997 estão disponíveis em CD-ROM e há, também, um acervo bastante completo na biblioteca Mário de Andrade em São Paulo.

Buscávamos, nesta etapa da pesquisa, entender a circulação da linguagem dos riscos numa perspectiva diacrônica e, certamente, trabalhar com um único jornal facilitava bastante essa tarefa. Entretanto, embora a palavra risco esteja disponível desde o século XVII, ela é incorporada na linguagem do cotidiano de formas distintas. É usada no sentido metafórico para falar de perigo e, paralelamente, é usada como conceito formal para falar do cálculo probabilístico do risco.

A primeira aproximação, portanto, teve esse caráter mais histórico buscando entender a diversidade de termos usados para falar do futuro como possibilidade de ganhos e perdas nesse jornal, no período de 1921 , data de criação da Folha de São Paulo, até 1998. Buscávamos, assim, criar um 'glossário sobre risco'. Para entender os usos feitos da linguagem dos riscos numa perspectiva diacrônica, a segunda parte da pesquisa, utilizamos uma amostra representativa de dias de 1921 a 1998. Tendo definido os dias que seriam incluídos na amostra, a equipe de pesquisa ia à biblioteca, lia cada exemplar dos jornais sorteados, da primeira à última página, de modo a identificar todas as matérias com a palavra risco no titulo. A terceira etapa foi um levantamento das matérias com risco no título no CD-ROM.

Quanto à análise, sendo esse um projeto quantitativo e qualitativo (pois, trabalhando numa perspectiva diacrônica, não daria para fazer apenas análises qualitativas), vários procedimentos foram adotados. Foi feita uma análise quantitativa dos termos associados a risco (o glossário do risco) utilizando o CD-ROM; buscamos também a frequência de aparecimento de matérias com risco no título nos jornais amostrados de 1921 a 1998. As matérias com risco no título na amostra e no CD-ROM foram então analisadas seguindo os procedimentos metodológicos do trabalho com práticas discursivas e para isso as matérias da amostra foram xerocadas e as 
do CD-ROM, impressas. Na fase qualitativa de análise das matérias localizadas pelo procedimento amostral, procuramos entender o uso da linguagem dos riscos por meio do fluxo de associação de ideias. Para isso usamos as Árvores de Associação de Ideias. Para as matérias localizadas no CD-ROM utilizamos o princípio da localização física (risco como chamada de primeira página) e temática da notícia: risco nas áreas emergentes; risco na saúde; risco na economia e risco no ambiente. Priorizamos, ainda, os novos e ambíguos usos (por exemplo, a linguagem dos riscos no esporte, no lazer), as experiências pessoais com risco e as poucas matérias que falavam da positividade do risco.

Que resultados obtivemos? Em primeiro lugar, a análise quantitativa permitiu uma melhor compreensão do "glossário do risco". Há uma variedade de palavras usadas para falar de ganho e perdas associados a eventos futuros: risco, ameaça, chance, perda, sorte, perigo, arriscado, obstáculo, azar, probabilidade, possibilidade, ventura, aventurar e fortuna. Para criar esse glossário foi preciso ter sensibilidade para a constelação de palavras que são usadas para se referir ao fenômeno em estudo. Isto vem em parte pela escuta (a observação de tipo etnográfico a que me referia anteriormente), em parte pelo conhecimento que temos da literatura. Tendo criado esse glossário, bastou usar o comando "localize" no CD-ROM para criar um gráfico de modo a poder visualizar a evolução da frequência de uso das diversas palavras do glossário.

Essa etapa quantitativa da pesquisa permite verificar o aumento no uso da palavra risco desde 1994. Assim, embora risco seja um vocabulário disponível há muitos séculos, e a despeito de sua formalização plena como conceito date da II Guerra Mundial, o termo não tem muita visibilidade na Folha de São Paulo (nos títulos de matérias desse jornal) até muito recentemente. As demais palavras do glossário de risco têm presença ainda menor, com tendência a decrescer, embora a minha aposta é que o termo aventura passará a ter uma presença mais marcante dada à maior visibilidade dos esportes radicais assim como também porque as experiências com engenharia genética tendem a ser descritas como uma grande aventura.

Em relação à análise diacrônica, a amostra de jornais foi definida (por uma profissional de estatística) a partir do cálculo do total de dias no período estudado. Dado que a amostra incluía 400 dias do jornal, de 1921 a
1998, imaginávamos encontrar muitas matérias com risco no título: localizamos vinte! Uma matéria antes da década de 80 , cinco na década de 80 e o resto tudo na década de 90 . Como a nossa definição de Linguagem dos Riscos incorpora tanto o uso formal como o uso informal, de senso comum, dessa palavra, utilizamos as seguintes categorias para análise dessas vinte matérias: (1) risco como perigo; (2) risco como probabilidade. Risco como perigo foi subdividido em duas subcategorias: as que focalizavam os atores (comportando ainda a divisão entre a perspectiva de quem corre o risco e a de especialistas) $e$ as que focalizavam os riscos em si. Para o foco nos riscos também foram definidas subcategorias tendo por foco as áreas em que se situavam os riscos: política, administração e energia. Obviamente, é nessas arenas que se dá a formalização do conceito de risco.

A presença ubíqua do risco como senso comum na mídia é interessante. De um lado, a linguagem dos riscos é introduzida para falar de uma mudança substantiva na forma de lidar com o futuro que ocorre na passagem da pré-modernidade para a modernidade clássica. Nessa acepção, justifica-se seu uso na linguagem de senso comum. Mas a noção não é apenas marca de uma nova sensibilidade; é também central para os processos de governamentalidade típicos da sociedade disciplinar. Nessa dimensão, é fundamental sua formalização para fins de cálculo, processo que leva cerca de trezentos anos. Para formalizar o conceito de risco é necessário que se torne disponível um instrumental técnico adequado, no caso a teoria da probabilidade, que se tornou efetivamente disponível apenas no final do século dezenove e no início do século vinte.

Esse processo de formalização do conceito de risco ocorreu na área da saúde (por meio de cálculos epidemiológicos), na economia (para gerenciar investimentos) e na área de seguros (que também está intimamente associada à saúde e segurança pública). Mas temos também o uso do conceito de risco, como probabilidade, na arena dos jogos, seja como aposta ou como investimento. Aliás, o desenvolvimento da teoria da probabilidade está intimamente relacionado com jogos e apostas. É essa vertente da linguagem dos riscos que parece informar a linguagem dos riscos em política: ao invés da probabilidade de ocorrência, o jogo eleitoral como aposta! 
Assim é essa reflexão cruzada entre o conhecimento da história do risco e a análise de práticas discursivas que permite chegar à diversidade de usos da linguagem dos riscos. Tomemos um exemplo das matérias assim localizadas: o risco do Clube Araraquarense de Futebol desaparecer. Aliás, essa matéria, datada de 1957, foi a mais antiga das vinte localizadas na análise diacrônica. Qual era o risco? O desaparecimento do clube devido à má administração. Portanto, nada tem a ver com cálculo de probabilidade. Fala-se do perigo de fechamento por estar o clube numa situação difícil: o presidente havia se demitido, não tinha uma diretoria, estava falido e o time nem compareceu ao certame! Risco, aqui, é meramente uma figura de linguagem.

$\mathrm{Na}$ análise da totalidade de matérias com risco no título registradas no CD-ROM da Folha de São Paulo, verifica-se o aumento paulatino de matérias com risco no título, especialmente a partir de 1997. Para entender esse uso, iniciamos a análise classificando as matérias por área: saúde e economia, áreas onde a linguagem dos riscos foi primeiro formalizada; política, esporte, lazer e ambiente e uma categoria residual (indefinido) para as matérias que não se encaixavam nas demais categorias. Como estávamos analisando essas matérias como parte de um Seminário Metodológico no curso de Mestrado em Psicologia Social da PUCSP, os alunos trabalharam essas classificações conjuntamente, buscando a concordância na forma de classificar. A análise quantitativa da frequência de matérias por área e ano permitiu ter um panorama geral das especificidades de uso da linguagem dos riscos.

Buscando ainda traçar um panorama geral, focalizamos a localização das matérias no jornal, com ênfase especial no risco como chamada de primeira página. Isso permite responder à pergunta: "o que faz risco ser notícia?" Respondendo: risco como chamada de primeira página refere-se, sobretudo à política e saúde.

As ameaças ao meio ambiente, na época em que fizemos a pesquisa, eram riscos emergentes, e só no final da década de 90 começavam a ter destaque. Os esportes de ação apareceram pouco e, de maneira geral, risco era utilizado como metáfora (e não como conceito formalizado). Encontramos, por exemplo, uma expressão emprestada da economia: "contrato de risco" para falar de uma modalidade de relação entre um profissional de esporte e seu time. Por exemplo, alguém de tal vai fazer um contrato de risco com o time por causa do problema do joelho.

$\mathrm{Na}$ política, risco permite o jogo da ambiguidade. Nessa área, encontramos apenas uma matéria com o uso formalizado de risco referindose à probabilidade de um candidato (se não me engano, era o saudoso Mário Covas) vencer a eleição do governo de São Paulo, com dados derivados de uma enquête. No lazer, os riscos vêm acoplados ao título de filmes e peças teatrais; assim, há inúmeras menções ao filme Risco Total que evidentemente inflacionaram o quantitativo do risco na área de lazer.

A longa perambulação pela literatura sobre risco me permite propor que a linguagem dos riscos emerge de duas tradições. A primeira está presa à questão da governamentalidade; a outra tem uma ascendência mais longa na história da humanidade e situa o risco como aventura. Na revisão da literatura, encontramos muitas pesquisas e reflexões sobre governamentalidade, seja no sentido coletivo de governo das populações, ou no sentido mais individualista das medidas de disciplinarização do corpo. Há, ainda, uma substancial literatura sobre risco e economia, tradição fronteiriça entre a governamentalidade e a aventura. Mas, até recentemente, havia pouca coisa sobre risco-aventura. Entretanto, é justamente a aventura que parece atualmente estar sinalizando para uma nova sensibilidade frente aos riscos. Essa é uma temática que vem me fascinando e que estarei focalizando na próxima etapa da pesquisa sobre risco.

Quero, nessa nova fase da pesquisa, entender a função do riscoaventura na modernidade tardia: uma sociedade destradicionalizada, onde mudam as demandas em termos de trabalho, de relações familiares, de intimidade. Há usos diversos dos esportes de aventura que podem fornecer pistas para compreensão do que parece ser a emergência de uma nova sensibilidade. No treinamento gerencial, para treino de flexibilidade e de espírito de equipe (talvez uma apropriação tardia da sociedade de controle daquilo que até então sobrevivia como resistência a ela). Na educação, como oportunidade para formação de caráter. A esse respeito, veja-se, por exemplo, a matéria de capa da revista Veja sobre crianças radicais (França, 1998) que fala dos pais que encorajam os filhos a fazer paraquedismo, escalada e rafting por serem essas atividades instrumentais no fortalecimento do caráter. Em 1999, aparece outra matéria de capa na Veja 
(França, 1999), desta vez sobre os "laços de adrenalina": dessa vez são as famílias que saem nos fins de semana para praticar esportes radicais que servem como elo afetivo, os laços de adrenalina, um lindo título para um belíssimo ensaio. Há ainda modalidades de risco decorrentes da paixão pelo risco: os modernos processos de ordálio que servem como contraponto aos processos de disciplinarização e que foram objeto de estudo de David Le Breton (1996).

O risco-aventura emerge, portanto, como uma arena perpassada pela polissemia, abrindo possibilidades interessantes para o estudo das transformações contemporâneas na maneira de ser pessoa. Se as primeiras fases da pesquisa forneceram uma visão panorâmica dos usos da linguagem dos riscos, nessa segunda etapa, intitulada Vivendo na Sociedade de Risco (Spink, 2000), nos propomos a explorar diferentes dimensões das experiências com risco na vida cotidiana. Para isso desenvolvemos uma metodologia específica, as Oficinas sobre Risco. Essa fase da pesquisa já está em vias de conclusão. Na fase seguinte voltarei à questão da circulação dos repertórios na mídia, dessa vez focalizando as imagens que vêm acompanhadas de referências a risco. As perguntas norteadoras, nesse caso, serão: qual o uso que se faz dessas imagens? Que retórica está emergindo para falar de riscos? Até que ponto as imagens sobre risco-aventura nos falam de novas formas de falar sobre risco?

A hipótese com a qual estou trabalhando (Spink, 2001) é que estamos vivenciando a passagem de uma sociedade pautada pela noção de risco para uma outra forma de sociabilidade onde a imponderabilidade, e não mais a esperança no controle por meio do cálculo, define Os processos de governamentalidade. Para viver com a imponderabilidade, temos que ter a flexibilidade que permita o enfrentamento da imponderabilidade; flexibilidade (e não a tradição) faz-se necessária.

\section{Por uma visão caleidoscópica da linguagem em ação: as conversas do cotidiano}

O próximo exemplo de pesquisa com práticas discursivas é particularmente interessante porque faz uma junção entre o uso de bancos de dados para pesquisar os repertórios linguísticos sobre menopausa e o estudo do uso desses repertórios no cotidiano. Essa pesquisa é de autoria de Vera Menegon (Menegon, 1998).
Inicialmente, tal como acontece na maioria das teses e dissertações de pesquisas em Psicologia, Vera pretendia trabalhar com entrevistas. A opção de trabalhar com conversas do cotidiano surgiu da própria imersão no campo. Costumo dizer que, embora a pesquisa científica exija eventualmente uma sistematização dos procedimentos de coleta e análise de dados, há uma atitude mais geral de pesquisador que nos leva, desde o momento em que definimos nossos objetivos de pesquisa, a estar "no campo".

Estar no campo significa prestar atenção aos inúmeros pequenos incidentes do cotidiano que estão associados ao tema de pesquisa. Portanto, recomendo aos alunos que andem com uma cadernetinha na bolsa ou no bolso. Assim, se aparece um programa de televisão, você o registra em seu caderno de campo; se sair uma matéria na mídia, você a recorta e arquiva; se ouvir uma conversa sobre o tema, você a anota. Em suma, registra tudo que tem a ver com o tema. Trata-se de uma atitude de pesquisa: a curiosidade que dá vida e cor à pesquisa mais do que o delineamento e execução do projeto propriamente dito. Ser pesquisador é estar em campo o tempo todo; estar atento às coisas que estão acontecendo e que podem trazer pistas valiosas sobre o problema de pesquisa.

A Vera fazia isso. Ela andava com o caderninho de campo na bolsa e começou a anotar conversas sobre o tema de pesquisa: a menopausa. Ela trazia essas conversas para a orientação e percebia o encantamento que suscitavam. Numa dessas sessões de orientação perguntei por que ela pretendia entrevistar pessoas já que estava encontrando material espontâneo tão rico. Por que não trabalhar com conversas!

Fizemos uma busca na bibliografia existente, buscando apoio metodológico para isso e resolvemos arriscar. Foi um exercício rico por possibilitar uma reflexão sobre o que consideramos ser fonte de dados; por permitir o exercício de análise de práticas discursivas em conversas do cotidiano e por impor a reflexão ética sobre o uso desse tipo de material.

A riqueza do material que encontramos espontaneamente é impressionante quando comparado com o material de entrevista que, em contraste, parece ser uma camisa de força. Não que o material coletado dessa forma seja melhor do que entrevista, ou melhor, do que questionário. Essa experiência com conversas, assim como os avanços teóricos sobre práticas discursivas, nos levou à constatação que cada uma dessas formas 
discursivas gera material diferente. Quando optamos por entrevistar (seja essa uma entrevista estruturada ou aberta), usar questionários, documentos de domínio público ou manifestações discursivas do cotidiano temos que fazer uma reflexão sobre que tipo de material tais procedimentos geram.

A pesquisa de Vera seguiu dois caminhos complementares. O primeiro visava compreender, em uma perspectiva histórica, que repertórios estavam disponíveis para dar sentido à menopausa hoje. Ciente da crescente medicalização da menopausa buscava também entender, por meio da literatura médica, como esse processo ocorreu e que aspectos da construção moderna da menopausa poderiam estar contribuindo para sua naturalização como problema médico. Com esse objetivo em vista, ela analisou a literatura científica da área biomédica, da Psicologia e das Ciências Sociais, incluindo aí produções históricas e contemporâneas, usando os principais bancos de dados da Medicina (Medline) e Psicologia (PsychInfo).

Nessa época, o Núcleo estava desenvolvendo outras pesquisas utilizando bancos de dados como fontes de informação sobre a construção de fatos científicos e havíamos aprendido muito sobre o uso de palavraschave para efetuar a busca. As palavras-chave também têm história, passando a serem usadas em determinados momentos da evolução da pesquisa ou teorização sobre um dado fenômeno. Na época em que Vera estava desenvolvendo sua pesquisa sobre menopausa, Lia Mirim (Mirim 1999) buscava entender a evolução do discurso sobre uso do teste para testagem do HIV e eu começava a pesquisa sobre risco (que em sua primeira fase utilizou bancos de dados). Fomos então desenvolvendo um know-how sobre o uso das palavras-chave como forma de construção de fatos sociais e de legitimação de um campo de saber. Os bancos de dados têm uma enorme influência na definição do que é considerado conhecimento legítimo em uma determinada área.

A adoção de um procedimento sistemático nessa busca é fundamental. A primeira lição que aprendemos é que faz mais sentido, metodologicamente, utilizar, como estratégia de busca, a palavra-chave no título. Ao usá-la como palavra solta, obtivemos uma grande quantidade de dados que nem sempre estão focados no problema em estudo. Trabalhamos, assim, primeiramente com títulos, depois com resumos e, a partir daí, temos mais segurança na escolha dos artigos a serem analisados. Ir do título para o resumo e depois para o artigo é uma forma de economizar tempo e garantir uma seleção mais criteriosa.

A partir da busca da palavra-chave no título, Vera localizou uma quantidade enorme de artigos sobre menopausa. Ela usou dois critérios de escolha de artigos para análise: aqueles que traziam uma retrospectiva histórica sobre a menopausa e os que possibilitavam entender o panorama contemporâneo. Os passos que ela seguiu e os resultados dessa fase da pesquisa estão explicitados na dissertação (Menegon,1998) pois o capítulo do livro Práticas Discursivas (Menegon,1999) prioriza a análise das conversas. Mas, sinteticamente, essa fase possibilitou que Vera entendesse como evoluíram os repertórios sobre menopausa, que nomeações foram dadas à menopausa em diferentes épocas, que tratamentos foram recomendados e que sintomas foram abordados. Esses aspectos permitiram que ela definisse e caracterizasse o processo de medicalização da menopausa, mostrando que ocorreu tanto a ampliação do conceito como a expansão da medicalização. No que se refere à nomeação, pela definição dada à pré-menopausa, a mulher, a partir da primeira menstruação já está a caminho da menopausa; ao passar por esta, entra na categoria da pósmenopausa. Mas houve também uma ampliação paulatina dos sintomas e consequentemente dos tratamentos. Certos tratamentos tiveram seus dias de glória, para pouco depois serem questionados ou abandonados. Assim, a reposição hormonal já foi considerada panaceia, mas atualmente há um significativo contingente de médicos que começa a se preocupar com os efeitos do uso de hormônios.

A segunda fase da pesquisa visava entender a circulação e uso desses repertórios no cotidiano e é aqui que entram as conversas. Por serem essas conversas fontes de dados pouco exploradas aqui no Brasil, foi necessário refletir, a cada passo da análise, sobre questões metodológicas que explorarei a seguir.

A primeira observação a fazer é que ao utilizar contextos do cotidiano como fontes de informação amplia-se o nosso campo de pesquisa: implica estar em campo o tempo todo. Vera registrou conversas em bares, durante as férias, em situações de lazer, etc. Evidentemente, nesse tipo de pesquisa não temos nenhum controle sobre o número de pessoas que serão incluídas na pesquisa ou sobre o nível de escolaridade, a idade ou o sexo dos participantes. Há também o problema de perda de várias situações, pois 
as conversas são muitas vezes tão fluídas, tão rápidas que não há tempo para registrá-las. Vera andava com um gravador na bolsa, mas nem sempre dava tempo de perguntar se podia gravar. Outras vezes a situação a pegou desprevenida e sem um gravador à mão.

Essa forma de coleta de dados exige também alguns cuidados especiais. Se, por um lado, a espontaneidade da situação produz um material menos formal, por outro, tem que aceitar o desafio que representa registrar e utilizar esses dados. As conversas com registro manual impedem alguns tipos de análise: por exemplo, não é possível fazer uma análise de conversação, pois isso exige uma transcrição minuciosa com registro de pausas, risadas e outros indicadores linguísticos (ou não linguísticos) que não são possíveis quando o registro é feito manualmente e nem sempre concomitantemente à situação observada.

Outro desafio é o aspecto ético. Vera usou 18 situações, tendo perdido três situações por achar que o registro não era confiável. Para 15 dessas 18 ela pôde pedir autorização para uso do material. Eram situações que envolviam pessoas conhecidas, ou passíveis de serem encontradas e foi possível pedir autorização retroativamente. Três situações tinham um caráter muito público. Discutimos longamente essas situações no Núcleo e consideramos que eram tão públicas que não havia necessidade de pedir autorização. Mesmo assim, como forma de assegurar o anonimato, ela usou nomes fictícios em todas as conversas e, ao descrever o contexto, modificou quaisquer elementos que pudessem identificar as pessoas.

Quanto aos procedimentos de análise, primeiramente ela analisou cada conversa individualmente, caracterizando o contexto da conversa e os participantes em termos do sexo e idade aproximada. Como eram conversas curtas, seguia, na apresentação dos dados, o registro da íntegra da conversa. Para cada conversa, Vera fez uma Árvore de Associação de Ideias, identificou os repertórios linguísticos usados para falar da menopausa e o uso desses repertórios procurando articular uso com os conteúdos identificados na literatura sobre o tema resultante da primeira fase da pesquisa.

Isso permitiu definir três temáticas que possibilitaram uma agregação das várias conversas: (1) magia e poder do sangue menstrual; (2) medicalização e (3) menopausa na perspectiva dos homens. Evidentemente essa escolha de temas derivou do diálogo entre a análise individual das conversas e a análise histórica dos repertórios sobre menopausa. Em suma, fez o que fazemos todos no processo de interpretação: estabelecemos um diálogo entre nosso material empírico, a revisão da bibliografia e o referencial teórico.

Fazendo uma breve apresentação dos resultados dessa fase da análise, a questão do poder (e magia) do sangue menstrual tinha como eixo norteador os impactos atribuídos à falta desse sangue, explicitando a simbiose entre sentidos antigos e novos. Dentre os repertórios aí presentes encontravam-se: a purificação do corpo pelo sangue; o sangue como símbolo de saúde; a menstruação como marcador da identidade da mulher e ainda a questão da sexualidade e procriação.

No que diz respeito à medicalização, a menopausa é cada vez mais vista como algo indesejado, que deve, portanto, ser tratada com intervenção medicamentosa. Muito embora o sentido mágico atribuído ao medicamento se faça presente, emergiu, nas conversas, certa ambivalência com relação a seus possíveis efeitos colaterais. Além disso, fizeram-se presentes repertórios variados que relevam os aspectos emocionais problemáticos que são tidos como decorrências da menopausa: depressão, tristeza, instabilidade emocional e daí por diante.

Finalmente, o terceiro tema - a menopausa vista na perspectiva dos homens - tinha como eixo norteador o impacto na vida pública. Falava-se das consequências negativas da menopausa no desempenho profissional e intelectual e na perda de atrativo físico. Fizeram-se presentes a ideia de estranhamento, o temor e a incompreensão do homem frente às singularidades biológicas da mulher. Sendo por demais complexa a análise e a discussão dos resultados, fica aqui o convite a ler o trabalho de Vera na íntegra. 


\section{CAPÍtULO IV}

\section{DÚVIDAS E QUESTÕES DOS PARTICIPANTES DO CURSO}

Pergunta: Ao ler o teu livro Práticas Discursivas, percebi que o Construcionismo Social choca-se com as Representações Sociais e com a Semiótica. Como é que tu vês esta questão? Tu acreditas que Semiótica e Construcionismo são incompatíveis? Representações Sociais e Construcionismo também são incompatíveis?

Mary Jane Spink: Esta questão é importante. Tomei o cuidado de começar este curso explicitando o posicionamento epistemológico justamente para ilustrar o que considero ser o caminho mais seguro para a pesquisa. As costuras teóricas são complicadas e em geral são feitas sem pensar criticamente sobre os pressupostos que estão embasando essas várias abordagens. Acho até difícil afirmar que Representações Sociais é uma abordagem única; trabalhei muitos anos nesse campo de estudos e sei que há, nesse campo, vertentes mais cognitivas e vertentes mais psicossociológicas. Por isso, é difícil colocar toda essa diversidade num mesmo referencial teórico.

Creio que é necessário fazer o trabalho crítico de contextualização dos autores que utilizamos. Fazemos isso por meio dos interlocutores. Ou seja, as pessoas se posicionam num cenário científico citando autores. São esses autores que vão indicar o tipo de afiliação teórica ou epistemológica; digo indicar porque muitas vezes não encontramos - nos livros, teses, dissertações, artigos - esclarecimentos sobre os pressupostos epistemológicos do autor. Alguns autores consideram-se dispensados de falar desses pressupostos porque falam a partir de uma dada postura que tem afiliações epistemológicas conhecidas; já outros são mesmo pouco cuidadosos. Muitos dos autores da Psicologia são pouco cuidadosos e misturam posições teóricas incompatíveis.

Durante esse curso falei que o trabalho com práticas discursivas exige que busquemos entender o contexto de produção e isso se aplica também às práticas discursivas da ciência. Temos que começar nossa reflexão perguntando a partir de que contexto de produção fala um determinado autor. Isso evita que façamos uma costura teórica impossível. Por exemplo, há autores do campo de estudo das representações sociais que se dizem construcionistas, entre eles Wolfgang Wagner. Acho essa postura equivocada; creio que é um casamento forçado. Participei recentemente da banca examinadora de uma dissertação defendida na Universidade Federal de Minas Gerais (Godoi, 2000). Nessa pesquisa, a autora tentava fazer uma aproximação entre Serge Moscovici e Richard Rorty. Acho que ela fez um belo trabalho de reflexão, mas, ao mesmo tempo, o texto explicita justamente essas dificuldades casamenteiras: ela acabou casando um Moscovici romântico com um Rorty irônico. Essas duas posturas são incompatíveis! Ela focalizou as possíveis semelhanças entre a proposta de Moscovici e o Construcionismo (na perspectiva da Psicologia Social): a ênfase no senso comum e a centralidade do cotidiano na produção de sentidos, por exemplo. Mas, analisando os autores com quem Moscovici conversa, vê-se que essa aproximação é inviável.

Começa sendo inviável porque Moscovici afirma que as Representações Sociais têm uma base em Durkheim. Se Moscovici tivesse eleito um outro sociólogo, por exemplo Weber, teria sido possível fazer uma aproximação com uma vertente teórico-metodológica mais voltada ao uso da linguagem, ou com a abordagem construcionista. Mas ele fez uma escolha mais objetivista, apoiando-se num dos autores mais positivistas da Sociologia: Durkheim.

Há uma belíssima entrevista, uma conversa entre Serge Moscovici e Ivana Marková (1998), onde Marková faz uma provocação sobre afirmações feitas por Moscovici a respeito das bases teóricas da noção de Representação Social. O diálogo segue mais ou menos assim: Durkheim?"

- Marková: "você fala que a sua noção de representação vem de

- Moscovici: "não, não vem de Durkheim, vem de Piaget. Vem de Durkheim, mas através de Piaget, porque a noção de representação de Piaget é de Durkheim".

— Marková: "mas você fala de Durkheim no livro A Psicanálise".

- Moscovici: "é, eu falo, mas na verdade eu não tinha lido Durkheim. Eu tinha lido só aquele texto que todo mundo leu Psicologia e Sociologia. Eu não conhecia o trabalho de Durkheim, eu fui conhecer depois quando publiquei A Máquina de Fazer Deuses". 
Por isso, essas heranças são complicadas. Moscovici tem o mérito de introduzir na Psicologia Social uma vertente mais social de reflexão sobre os fenômenos que são objetos de estudo dessa disciplina. Sem dirimir esse mérito, o que estou querendo apontar é que temos que ser críticos sobre os autores que elegemos como interlocutores: no caso de Moscovici, temos que refletir sobre as implicações da herança durkheimiana. Quando alguém sinaliza que sua base teórico-epistemológica é durkheimiana, passamos a questionar a possibilidade de chamar essa vertente teórica de construcionista, certo?

As vozes que trazemos para nosso texto são extremamente importantes quando buscamos manter a coerência epistemológica. Isso é básico. Assim, há vários autores que vêm buscando dar uma dimensão mais construcionista à teoria das representações sociais. Considerando essa aproximação inviável, minha opção foi mudar de percurso, não apenas por ter adentrado pelas reflexões construcionistas sobre a produção de conhecimento, mas também porque passei a me interessar mais pelo aqui-eagora da interação e isso me levou a uma aproximação com a Psicologia Discursiva. Não me parecia possível conciliar esse interesse pela fluidez das trocas discursivas com o enquadre teórico das Representações Sociais. Começa que as Representações Sociais são definidas como conteúdos compartilhados e eu estava mais interessada nos processos de negociação de sentidos do que no compartilhamento de representações.

Há uma questão importante e pouco discutida na pesquisa em Psicologia (e nas ciências sociais em geral): os níveis de análise. Podemos trabalhar em um único nível de análise ou em vários níveis de análise. Esses níveis englobam toda a gama de possibilidades: do nível macro - como fazem muitos sociólogos - até o micro: a pessoa, na perspectiva individualista, ou a interação entre pessoas, na perspectiva dialógica adotada pela Psicologia Discursiva.

Quem estuda Representações Sociais trabalha num nível de análise intermediário que prioriza os aspectos coletivos, compartilhados do fenômeno; no mesmo nível que trabalha a Epidemiologia. Como o foco é no compartilhamento, trabalha-se com dados agregados; trabalha-se com conteúdos discursivos de muitos para identificar o que há de semelhante. É possível até trabalhar com diferenças, mas não com as incoerências e com os processos de negociações de sentidos que é o que interessa à Psicologia Discursiva.

Seriam então incompatíveis a análise de práticas discursivas na perspectiva do Construcionismo e o estudo das Representações Sociais? Epistemologicamente creio que há incompatibilidade. Do ponto de vista dos níveis de análises, pelo menos da forma em temos trabalhado no Núcleo, quando focalizamos a circulação dos repertórios linguísticos há algumas semelhanças com o que é feito no estudo das representações. Mas semelhanças de objetivos não devem ser extrapoladas para semelhanças teóricas. Por isso, acho recomendável tomar cuidado ao buscar fazer pontes entre representações sociais e análise de práticas discursivas pois essas abordagens vêm de duas tradições diferentes de pesquisar e de pensar a Psicologia.

Quanto à Semiótica, o pouco que sei sobre essa disciplina me leva a pensar que ela tem sua base no estruturalismo. O estruturalismo parte do princípio de que há uma estrutura subjacente à superfície dos fenômenos observáveis; assenta-se, portanto, numa ontologia realista e essencialista. Então é preciso ter um certo cuidado ao aproximar as vertentes estruturalistas da Semiótica às abordagens construcionistas que são, por definição, antiessencialistas. A Semiótica tende a essencializar, sobretudo, a noção de símbolo. Mas sendo a Semiótica um campo de complexidade, e não estando familiarizada com a diversidade de postura aí existentes, não ousaria fazer mais do que esse alerta sobre uma potencial incompatibilidade entre a noção de símbolo (e seu significado) e de sentidos produzidos no fluxo das interações cotidianas.

O contraste que estou procurando fazer entre símbolos (significados) e repertórios (sentidos) é semelhante ao contraste, na Psicologia Social, entre papéis e posicionamentos (posições de pessoa). A noção de papéis tem um ranço de essencialismo. Já a noção de posicionamento é absolutamente fluída: as posições de pessoa são posições evocadas no processo de interanimação dialógica que pontua nossas interações.

Pergunta: Na análise dos dados, nós temos nossa teoria também; vamos construir algo novo, então, de repente, citamos uma frase daqui e tal, dentro de um novo contexto maior. Corno é que tu vês isto? Temos que ter cuidado para manter sempre um mesmo contexto ou a gente veste a camiseta e faz isso mesmo? 
Mary Jane Spink: Acho que temos que ter cuidado de deixar claro sempre o contexto a partir do qual estamos falando; preservar a visão do todo para que o processo de interpretação possa ser compreendido por nossos interlocutores. Por exemplo, ao descrever os procedimentos, estamos fornecendo contextos: fiz dez entrevistas, escolhi fazer dez por tal razão, entrevistei tais pessoas, as entrevistas foram feitas da seguinte forma.

Também a análise busca fazer esse jogo de contextos dentro de contextos. Começamos, em geral, fazendo uma análise de cada entrevista (conversa, documento, grupo, etc.) isoladamente. Descrevemos o contexto em que ocorreu a entrevista, a dinâmica; fazemos transcrições sequenciais, buscamos entender as temáticas presentes, etc. Buscamos sempre preservar a totalidade de tal modo que, ao analisar a parte, seja possível aos nossos interlocutores situá-la no contexto mais amplo que permite entender o contexto de produção de sentidos.

As análises individuais passam a ser então partes de um novo todo: o conjunto das entrevistas. Essa segunda etapa tende a ser uma análise temática. Na pesquisa de Vera, por exemplo, a partir da análise das 18 conversas e do cruzamento disso com a fase de familiarização com os repertórios históricos sobre a menopausa, ela realizou sua síntese a partir de três grandes temas: o sangue mágico, a medicalização e a menopausa na visão masculina. As 18 conversas foram então utilizadas para ilustrar os três temas-síntese.

Pergunta: Você poderia falar um pouco sobre a questão da nomeação?

Mary Jane Spink: O foco na nomeação traz uma série de vantagens analíticas. Nada melhor para entender como muda um fenômeno diacronicamente do que acompanhar as mudanças de nomeação. Também não há nada melhor para entender as nuances do fenômeno em estudo nas práticas discursivas - numa entrevista, por exemplo - do que acompanhar a trajetória de nomeações.

Por exemplo, na pesquisa sobre câncer, há diversas palavras que poderiam ser usadas para se referir a ele: o tumor, a doença, o mal, etc. $\mathrm{O}$ glossário é bastante diversificado e as pessoas tendem a utilizar esses termos em momentos específicos da entrevista. Há ainda momentos no enfrentamento da doença em que nem é possível nomeá-la. A ausência de nomeação é também uma forma de dar sentido à negatividade da doença. Pesa aí, também, o que Harré (1998) denomina de gramática dos pronomes: a nomeação de quem fala - eu, nós, a gente - é um indicador potente das dimensões de pessoa que estão sendo invocadas.

Pergunta: A senhora chega a trabalhar com a incursão de persecutórios, assim, como, por exemplo, nós temos uma função ideológica, uma função de resistência?

Mary Jane Spink: Claro, a base da análise histórica dos riscos, por exemplo, é a função da linguagem dos riscos nos processos de disciplinarização. Estamos no plano ideológico, portanto. Ao trabalhar com repertórios, estamos trabalhando com a linguagem em uso e esses usos remetem às consequências sociais. Na revisão histórica feita na pesquisa sobre risco isso fica evidente. No momento, venho buscando entender a mudança da sociedade disciplinar para uma sociedade pautada no gerenciamento dos riscos, ou seja, de uma sociedade onde os processos disciplinares eram baseados em vigilância para uma sociedade pautada pelos biopoderes. Busco entender como essa nova linguagem de risco voltada ao esporte-aventura está sendo apropriada como parte dos processos de disciplinarização e como ela está sendo utilizada pelos movimentos de resistência à sociedade de risco. Então, com certeza, a função ideológica se faz presente.

Pergunta: Quando se trabalha com grupos focais, como se faz o mapa? Ou não se usa o mapa?

Mary Jane Spink: A primeira coisa que recomendo fazer - e isso vale para qualquer material mais complexo, como entrevistas longas e grupos - é uma análise sequencial. No caso dos grupos, a análise pode ser temática ou ser uma análise de sequencias de temas. O que estou chamando de Análise Temática é o que a Vera fez: uma síntese dos principais aspectos em termos de conteúdo. Já a Análise de Sequencias de Temas está voltada à compreensão da dinâmica do grupo. O primeiro passo na análise de um material interativo complexo, seria esse. Começamos fazendo uma descrição do todo a partir da transcrição sequencial e, se optamos por fazer recortes, justificamos essas escolhas. Para a construção do mapa propriamente dito, há atualmente uma série de técnicas que podem ser usadas se o material gravado estiver transcrito e informatizado. Há uma série de facilidades de cortar e colar que ajudam a entender melhor o 
material analisado. $\mathrm{O}$ uso de mapas na pesquisa com grupos depende do foco: os temas ou as sequencias de temas; ou seja, se o foco são os repertórios (podendo nesse caso aproximar-se de uma pesquisa sobre Representação Social) ou os processos de produção de sentido.

Tenho uma orientanda que está trabalhando com um material muito complexo: um grupo que ela fez com os doutores da alegria. Participaram deste grupo, profissionais da área da saúde, palhaços e artistas. Passamos um tempo acertando as colunas do mapa e ela começou transcrevendo, como exercício; e eu quietinha, esperando ver até onde ela aguentaria, pois eram duas fitas de gravação transcritas. Na orientação seguinte ela disse: "ai meu Deus, eu só fiz quatro páginas da transcrição e já deu tudo isso". Sugeri então que ela voltasse à transcrição sequencial, numerasse todas as linhas da transcrição e buscasse entender a relação entre temas emergentes e personagens: psicólogos, médicos, palhaços, etc.; que analisasse, portanto, apenas os temas de maior interesse teórico, mantendo a distinção entre posições de pessoa, mas mantendo a relação com o todo pela explicitação das linhas a que o conteúdo do mapa estava se referindo.

Essa é uma forma de lidar com material complexo. Mas tudo isso remete à nossa sede de coletar dados: se fizéssemos uma pesquisa sobre coletas de dados de pesquisa, verificaríamos que o que acaba entrando na análise é, em geral, uma pequena porcentagem do que foi coletado. Coletase muito mais do que conseguimos analisar porque muitas vezes saímos a campo sem ter clareza sobre nossos objetivos. Então dizemos: "como não sei bem o que estou procurando, vou coletar tudo que dá, e depois eu decido o que analisar".

Por isso, é importante fazer algumas experiências anteriores: fazer entrevistas piloto; sair a campo e observar. Todas essas coisas que chamávamos de fase piloto são importantes porque permitem entender melhor o material com o qual estamos trabalhando e o que estamos querendo saber. Nos exemplos de pesquisa que discuti durante este curso, essa fase inclui a compreensão do uso espontâneo de palavras para falar de um fenômeno.

Pergunta: Em um grupo focal é importante que se coloque qual participante falou tal ou qual frase e manter na sequencia quem está falando?
Mary Jane Spink: Com certeza. Nem sempre é possível identificar o locutor na gravação das falas. Então, para auxiliar a recordar, fazemos um diagrama situando a posição de cada participante do grupo. Os esquemas visuais têm um certo poder de ancorar memórias imagéticas, então a primeira coisa que faço, antes de transcrever, de ouvir a fita e transcrevê-la, é situar esquematicamente quem estava sentado onde e aí, é curioso, porque você ouve as falas e diz: "aquela voz estava ali, então era aquela pessoa". Isso é importante quando fazemos um grupo focal para o processo de negociação de sentidos. 


\section{REFERÊNCIAS}

BAKHTIN, M. The problem of speech genres. In: Emerson, C.; Holquist, M. (Eds.), Speech Genres and other late essays. Austin, Texas: University of Texas Press, 1994. p. 60-102.

BASKAR, R. Beef, structure and place: notes from a critical naturalist perspective. Journal for the Theory of Social Behaviour, v. 13, n. 1, p. 81-95, 1983.

BECK, U. Risk Society - towards a new modernity. London: Sage, 1993. (Published in Germany in 1986).

BERGER, P.; LUCKMANN, T. A construção social da realidade. Petrópolis: Vozes, 1976. (Trabalho original publicado em 1966).

BOURDIEU, P. O campo científico. In: Pierre Bourdieu - Sociologia. São Paulo: Editora Ática, 1983. p. 122-155. (Trabalho original publicado em 1976).

. Structures, Habitus and Practices. In: The polity reader in social theory. Cambridge: Polity Press, 1994. p. 95-110.

CIAMPA, A. C. A história de Severino e a estória de Severina. São Paulo: Brasiliense, 1987.

DANZINGER, Kurt. The varieties of social construction. Theory and Psychology, v. 7, n. 3, p. 399-416, 1997.

DAVIES, B.; HARRÉ, R. Positioning: the discursive production of selves. Journal for the Theory of Social Behaviour, v. 20, n. 1, p. 43-63, 1990.

FLECK, L. Genesis and Development of a Scientific Fact. Chicago: University of Chicago Press, 1979. (Trabalho original publicado em 1935).

FRANÇA, V. Uma turma movida à adrenalina. Reportagem de Capa. Veja, São Paulo, p. 12-18, 11 mar 1998.

Laços de adrenalina. Reportagem de Capa. Veja, São Paulo, p. 16-21, 2 jun. 1999.
GERGEN, K. The social constructionist movement in modern Psychology. American Psychologist, v. 40 n. 3, p. 266-275, 1985.

GIDDENS, A. Risk Society: the Context of British Politics. In: Franklin, J. (Ed.). The politics of risk society. Cambridge: Polity Press, 1998. p. 23-34.

GODOI, C. A. M. B. Sobre uma possível convergência entre a teoria das representações sociais $e$ as ideias de Rorty em "A filosofia $e$ o espelho da natureza”. 2000. Dissertação (Mestrado em Psicologia) Universidade Federal de Minas Gerais, Belo Horizonte, 2000.

HACKING, Ian. Why ask what? In: Hacking, I. The social construction of what? Cambridge, Mass: Harvard University Press, 1999. p. 1-34.

HARRÉ, R. The singular self. Sage, 1998.

IBÁÑEZ, T. Henri, Serge and the next generation. Newsletter of the social psychology section, v. 24, p. 5-14, 1991

Construccionismo y psicologia. Revista Interamericana de Psicologia, v. 28, n. 1, p. 105-123, 1993.

La construccion dei conocimiento desde una perspectiva socioconstrucionista. In: Montero, M. (Org.) Conocimiento, realidad e ideología. Caracas: Associacion Venezoelana de Psicología Social - AVEPSO, 1994. p. 39-48.

KHUN, T. The structure of scientific revolutions. Chicago: University of Chicago Press, 1970 (1 $1^{\mathrm{a}}$ ed.: 1962).

KNORR-CETINA, K. D. The manufacture of knowledge: an essay ou the constructivist and contextual nature of science. Oxford: Pergamon, 1981

LAQUEUR, T. Making sex: body and gender from the Greeks to Freud. Cambridge, Mass.: Harvard University Press, 1990.

LATOUR, B. Science in action. Cambridge, Mass.: Harvard University Press, 1987.

LE BRETON, D. Passions du Risque. Paris: Métailié, 1996. 
MENEGON, V. S. M. Menopausa: imaginário social e conversas do cotidiano. Dissertação (Mestrado em Psicologia Social) - Pontifícia Universidade Católica de São Paulo - PUCSP, 1998.

Por que jogar conversa fora? Pesquisando no cotidiano. In: Spink, M. J. P. (Org.). Práticas discursivas e produção de sentidos no cotidiano. São Paulo: Cortez, 1999. p. 215-242.

MIRIM, L. Y. L. Garimpando sentidos em bases de dados. In: Spink, M. J. P. (Org.). Práticas discursivas e produção de sentidos no cotidiano. São Paulo: Cortes, 1999. p. 153-182.

MORIN, E. O problema epistemológico da complexidade. Lisboa: Publicações Europa-América, 1985.

MOSCOVICI, S.; MARKOVÁ, I. Presenting social representations: a conversation. Culture \& Psychology, v. 4, n. 3, p. 371-410, 1998.

PINHEIRO, O. de G. O sentido das queixas de usuários de um Serviço de Saúde Mental: uma análise discursiva. Tese (Doutorado em Psicologia Social) - Pontifícia Universidade Católica de São Paulo PUCSP, 1998.

.Entrevista: uma prática discursiva. In: Spink, M. J. P. (Org.). Práticas discursivas e produção de sentidos no cotidiano. São Paulo: Cortez, 1999. p. 183-215.

POTTER, J.; WETHERELL, M.; GILL, R.; EDWALDS, D. Discourse: noun, verb or social practice. Philosophical Psychology, v. 3, n. 2, p. 205-217, 1990.

RORTY, R. A filosofia e o espelho da natureza. Rio de Janeiro: RelumeDumará, 1995. (Trabalho original publicado em 1979).

SANTOS, B. de S. A crítica da razão indolente. São Paulo: Cortez, 2000.

SPINK, M. J. P. (1993). O contexto como pretexto. In: ENCONTRO INTERAMERICANO DE PSICOLOGIA, XXIV. Santiago-Chile, 4 a 9 de julho, 1993. (mimeo).

Permanência e diversidade nas representações sociais da hipertensão arterial essencial. Temas em Psicologia, v. 2, p. 199-212, 1994a.
Desvendando as teorias implícitas: uma metodologia de análise das representações sociais. In: Jovchelovith, S.; Guareschi, P. (Orgs.). Textos em representações sociais. Petrópolis: Vozes, 1994b. p. 117-145.

A medicina e o poder de legitimação das construções sociais de igualdade e diferença: uma reflexão sobre cidadania e gênero. In: Spink, M. J. P. (Org.). A cidadania em construção: uma reflexão transdisciplinar. São Paulo: Cortez. 1994c. p. 93-103.

O sentido da doença: a contribuição dos métodos qualitativos na pesquisa sobre câncer. In: Gimenes, Maria da Glória G. (Org.). A mulher diante do câncer: pesquisa e práticas em Psiconcologia. Campinas: Editoria Psi II, 1997a. p. 197-224.

A construção social do risco no cenário da AIDS. Projeto Integrado de Pesquisa, CNPq (vigência 1998-2000). 1997b. (mimeo).

Risco e sociedade contemporânea: vivendo na sociedade de risco. Projeto Integrado de Pesquisa, CNPq (vigência 2000-2002). 2000. (mimeo).

Os contornos do risco na modernidade reflexiva: considerações a partir da Psicologia Social. Psicologia e Sociedade, v. 12, n. 1/2, p. $156-173,2001$

Trópicos do discurso sobre risco: risco-aventura como metáfora na modernidade tardia. Cadernos de Saúde Pública, v. 17, p. 12771311, 2001.

SPINK, M. J. P.; GIMENES, M. da G. G. (Orgs.). Práticas discursivas e produção de sentido: apontamentos metodológicos para a análise de discursos sobre a saúde e a doença. Saúde e Sociedade, v. 3, n. 2, p. 149-171, 1994.

SPINK, M. J. P.; LIMA, H. Rigor e visibilidade: a explicitação dos passos da interpretação. In: Spink, M. J. P. (Org.). Práticas discursivas $e$ produção de sentidos no cotidiano. São Paulo: Cortez, 1999. p. 93122.

SPINK, M. J.; MEDRADO, B. Produção de sentido no cotidiano: uma abordagem teórico-metodológica para análise das práticas 
discursivas. In: Spink, M. J. P. (Org.). Práticas discursivas $e$ produção de sentidos no cotidiano. São Paulo: Cortez, 1999. p. 4161.

SPINK, M. J. P.; MENEGON, V. A pesquisa como prática discursiva. In: Spink, M. J. P. (Org.). Práticas discursivas e produção de sentidos no cotidiano: aproximações teóricas e metodológicas. São Paulo: Cortez, 1999. p. 63-92.

SPINK et al. Reflexão e Crítica, 15, p. 151-164, 2002.

TONNELLI, Maria José. Os sentidos das máquinas: novas tecnologias e a aceleração do cotidiano de trabalho. Tese (Doutorado em Psicologia Social) - Pontifícia Universidade Católica de São Paulo, 2000.

VATTIMO, G. O fim da modernidade: niilismo e hermenêutica na cultura pós-moderna. São Paulo: Martins Fontes, 1996. (Edição italiana original, 1985).

WOOLGAR, S. Science: the very idea. Chichester: Ellis Harwood; London: Tavistock, 1988. 